\title{
Ambient temperature and cardiovascular mortality: A systematic review and meta-analysis
}

\author{
Ali Ardalan ${ }^{1,2,3}$, Mohammad Taghi Moghadamnia ${ }^{\text {Corresp., }}{ }^{1}$, Alireza Mesdaghinia ${ }^{4}$, Abbas Keshtkar ${ }^{5}$, Kazem \\ Naddafi $^{4}$, Mir Saeed Yekaninejad ${ }^{6}$ \\ 1 Department of Disaster Public Health, Tehran University of Medical Sciences, Tehran, Iran \\ 2 National Institute of Health Research, Tehran University of Medical Sciences, Tehran, Iran \\ 3 Harvard Humanitarian Initiative, Harvard University, Cambridge, United States \\ 4 Department of Environmental Health Engineering, Tehran University of Medical Sciences, Tehran, Iran \\ 5 Department of Health Sciences Education Development, Tehran University of Medical Sciences, Tehran, Iran \\ 6 Department of Epidemiology and Biostatistics, Tehran University of Medical Sciences, Tehran, Iran \\ Corresponding Author: Mohammad Taghi Moghadamnia \\ Email address: m-moghadamnia@razi.tums.ac.ir
}

Introduction: Our study aims at identifying and quantifying the relationship between the cold and heat exposure and the risk of cardiovascular mortality through a systematic review and meta-analysis Material and Methods: A systematic review and meta-analysis were conducted based on the Preferred Reporting Items for Systematic Reviews and MetaAnalyses (PRISMA) guideline. Peer-reviewed studies about the temperature and cardiovascular mortality were retrieved in the MEDLINE, Web of Science; and Scopus databases from January 2000 up to the end of 2015. The pooled effect sizes of short-term effect were calculated for the heat exposure and cold exposure separately. Also, we assessed the dose-response relationship of temperature-cardiovascular mortality by a change in units of latitudes, longitude, lag days and annual mean temperature by Metaregression. Result: After screening the titles, abstracts and full texts; 26 articles were included in the meta-analysis. The risk of cardiovascular mortality increased by $5 \%$ (RR, $1.055 ; 95 \% \mathrm{Cl}, 1.050$ to 1.060$)$ for the cold exposure, $1.3 \%(\mathrm{RR}, 1.013 ; 95 \% \mathrm{Cl}, 1.011$ to 1.015) for the heat exposure. The short-term effects of cold and heat exposure on risk of cardiovascular mortality in males were $3.8 \%(\mathrm{RR}, 1.038 ; 95 \% \mathrm{Cl}, 1.034$ to 1.043$)$ and 1.1 $\%(\mathrm{RR}, 1.011 ; 95 \% \mathrm{Cl}, 1.009$ to 1.013$)$ respectively. Moreover, effects of cold and heat exposure on risk of cardiovascular mortality in females were $4.1 \%(\mathrm{RR}, 1.041 ; 95 \% \mathrm{Cl}$, 1.037 to 1.045 ) and $1.4 \%$ (RR, $1.014 ; 95 \% \mathrm{Cl}, 1.011$ to 1.017 ) respectively. In the elderly, it was at $8.1 \%$ increase and $6 \%$ increase in the heat and cold exposure respectively. The greatest risk of cardiovascular mortality in cold temperature was in the 14 lag days (RR, $1.09 ; 95 \% \mathrm{Cl}, 1.07$ to 1.010$)$ and in hot temperature in the 7 lag days (RR, $1.14 ; 95 \% \mathrm{Cl}$, 1.09 to .)(1.17 The significant dose-response relationship of latitude and longitude in cold exposure with cardiovascular mortality was found. The results showed that the risk of 
cardiovascular mortality increased with each degree increased significantly in latitude and longitude in cold exposure $(0.2 \%, 95 \% \mathrm{Cl}:(0.006-0.035)$ and $(0.07 \%, 95 \% \mathrm{Cl}: 0.0003-$ $0.014)$ respectively. The risk of cardiovascular mortality increased with each degree increase in latitude in heat exposure $(0.07 \%, 95 \% \mathrm{Cl}: 0.0008-0.124)$. Conclusion: Our findings indicate that the increase and decrease in ambient temperature had a relationship with the cardiovascular mortality. To prevent the temperature- related mortality, persons with cardiovascular disease and the elderly should be targeted. The review has been registered with PROSPERO (registration number CRD42016037673). 


\title{
Ambient temperature and cardiovascular mortality:
}

\section{A systematic review and meta-analysis}

\begin{abstract}
Ali Ardalan', Mohammad Taghi Moghadamnia², Alireza Mesdaghinia ${ }^{3}$, Abbas Keshtkar ${ }^{4}$, Kazem Naddafi $^{5}$, Mir
\end{abstract} Saeed Yekaninejad ${ }^{6}$

${ }^{1}$ Department of Disaster Public Health, School of Public Health, Tehran University of Medical Science, Tehran, Iran

${ }^{1}$ National Institute of Health Research, Tehran University of Medical Science, Tehran, Iran.

${ }^{1}$ Harvard Humanitarian Initiative, Harvard University, Cambridge, USA.

${ }^{2}$ Department of Disaster Public Health, School of Public Health, Tehran University of Medical Science, Tehran, Iran

${ }^{3}$ Department of Environmental Health Engineering, School of Public Health, Tehran University of Medical Sciences; Institute for Environment Research, Tehran, Iran.

${ }^{4}$ Department of Health Sciences Education Development, School of Public Health, Tehran University of Medical Sciences, Tehran, Iran.

${ }^{5}$ Department of Environmental Health Engineering, School of Public Health, Tehran University of Medical Sciences; Institute for Environment Research, Tehran, Iran.

${ }^{6}$ Department of Epidemiology and Biostatistics, School of Public Health, Tehran University of Medical Sciences, Tehran, Iran.

Corresponding author: Mohammad Taghi Moghadamnia

\section{Abstract:}

\section{Introduction:}

Our study aims at identifying and quantifying the relationship between the cold and heat exposure and the risk of cardiovascular mortality through a systematic review and meta-analysis

\section{Material and Methods:}

A systematic review and meta-analysis were conducted based on the Preferred Reporting Items for Systematic Reviews and Meta-Analyses (PRISMA) guideline. Peer-reviewed studies about the temperature and cardiovascular mortality were retrieved in the MEDLINE, Web of Science; and Scopus databases from January 2000 up to the end of 2015. The pooled effect sizes of short-term 
effect were calculated for the heat exposure and cold exposure separately. Also, we assessed the dose-response relationship of temperature-cardiovascular mortality by a change in units of latitudes, longitude, lag days and annual mean temperature by Meta-regression.

\section{Result:}

After screening the titles, abstracts and full texts; 26 articles were included in the meta-analysis. The risk of cardiovascular mortality increased by 5\% (RR, 1.055; 95\% CI, 1.050 to 1.060) for the cold exposure, $1.3 \%$ (RR, 1.013; 95\% CI, 1.011 to 1.015$)$ for the heat exposure. The short-term effects of cold and heat exposure on risk of cardiovascular mortality in males were $3.8 \%$ (RR, 1.038; 95\% CI, 1.034 to 1.043 ) and $1.1 \%(\mathrm{RR}, 1.011$; 95\% CI, 1.009 to 1.013 ) respectively.

Moreover, effects of cold and heat exposure on risk of cardiovascular mortality in females were $4.1 \%$ (RR, $1.041 ; 95 \% \mathrm{CI}, 1.037$ to 1.045$)$ and $1.4 \%$ (RR, $1.014 ; 95 \% \mathrm{CI}, 1.011$ to 1.017$)$ respectively. In the elderly, it was at $8.1 \%$ increase and $6 \%$ increase in the heat and cold exposure respectively. The greatest risk of cardiovascular mortality in cold temperature was in the 14 lag days (RR, 1.09; 95\% CI, 1.07 to 1.010) and in hot temperature in the 7 lag days (RR, 1.14; 95\% CI, 1.09 to 1.17). The significant dose-response relationship of latitude and longitude in cold exposure with cardiovascular mortality was found.

\section{Conclusion:}

Our findings indicate that the increase and decrease in ambient temperature had a relationship with the cardiovascular mortality. To prevent the temperature- related mortality, persons with cardiovascular disease and the elderly should be targeted.

The review has been registered with PROSPERO (registration number CRD42016037673). 


\section{Introduction}

2 The relationship between climate change and health is considered to be a major concern in the 3 health care system(Cheng \& $\mathrm{Su} 2010)$. Exposure to hot temperature is associated with the 4 physiological changes which include: increased plasma viscosity and cholesterol levels in 5 serum(Lin et al. 2013b). Some studies have demonstrated that ambient temperature has effects on 6 the overall mortality (Huang et al. 2012; Lin et al. 2013b; Rocklöv et al. 2010). The relationship 7 between ambient temperature and mortality has been described as a J, V, or U-pattern (Huang et 8 al. 2014; Lin et al. 2013b; Ryti et al. 2015).

9 The relationship between temperature, morbidity, and mortality is mediated by direct and indirect ecological processes(Habib et al. 2010). The majority of deaths due to heat waves affect individuals with pre-existing cardiovascular disease(Pfeiffer 2011).Some studies have further

12 shown that increases in cardiovascular diseases (CVD) is associated with both cold and hot temperatures(Bhaskaran et al. 2009).

Acute coronary syndrome (ACS) usually occurs in the late stages of coronary heart disease(CHD) and is one of the leading causes of death in the world(Li et al. 2011). The significant inverse relation between temperatures and acute coronary syndrome (ACS) incidence suggests that the coldness may play an important role in the incidence of ACS. Some studies have reported greater mortality in cold weather than heat-related mortality(Gomez-Acebo et al. 2013; MedinaRamón \& Schwartz 2007). In addition, the heat wave effects appear in short time whereas the effects of cold spells may persist for up to 2 months(Goggins et al. 2013b; Xie et al. 2012). The harmful effects of cold and heat are strongly apparent in CVDs (Zhou et al. 2014). New research indicates that global warming, increasing ambient temperatures, and heat- related effects are of particular importance in the public health perspective(Turner et al. 2012).

The effects of temperature based on individual, social, economic and geographic factors are different. The poor and the elderly with underlying medical conditions, and those living in big cities are considered particularly vulnerable( $\mathrm{Ng}$ et al. 2014). The relationship between mortality 
27 and temperature may be dependent on the latitude. Thus, it is necessary that some studies be carried 28 out in areas of different latitudes(Ahmadnezhad et al. 2013; Shonkoff 2012).

29 Therefore, our study aims at identifying and quantifying the relationship between cold and heat 30 exposure and risk of cardiovascular mortality through a systematic review and meta-analysis.

$31 \quad$ Materials and method

32 A systematic review and meta-analysis were conducted based on the Preferred Reporting Items 33 for Systematic Reviews and Meta-Analyses (PRISMA) guidelines.

\section{Search strategy and sources}

Peer-reviewed studies about temperature and cardiovascular mortality were retrieved in the databases which included: MEDLINE (via PubMed); Web of Science; and Scopus, from January 2000 up to the end of 2015. Reference lists of the selected studies were scanned in order to identify any further studies. To access important "gray literature 'we examined the following websites: World Health Organization; Intergovernmental Panel on Climate Change; National Institutes of Health (USA) and Department for Environment, Food, and Rural Affairs (UK).

\section{Search keywords and terms}

We conducted a systematic search in two phases. In the primary investigation, the following keywords were used: ("weather" or "climate") and "cardiovascular diseases". All sub-terms were also included but we limited the search only to human studies published in English.

Then secondary search similar to primary was followed although we used more specific terms for CVDs such as “myocardial infarct*”, “coronary event”, " heart attack', “Q wave infarct*”, “"non-Q wave infarct*”, "Acute coronary syndrome”, "QWMI”, "NQWMI”, "STEMI”, "NSTEMI", "coronary infarct*”, "heart infarct*”, "myocardial thrombosis", "coronary thrombosis", "congestive heart failure" and "heart failure". The specific terms for ("weather" or “climate") were used if included "temperature", " ambient temperature", "cold temperature", "hot temperature", where " **, indicates any word ending.

\section{Selection of articles}

$$
\text { The following eligibility criteria were used in this study: }
$$

1. Studies applying time-series regression research design and case-crossover study design. 
55

56

57

58

59

60

61

62

63

64

65

66

67

68

69

2. The nonlinear model statistical analysis (DLNM or GAM) in the time series studies. These methods show the effect of exposure event to be distributed over a specific period of time, using several parameters in explaining the contributions at different lags, thus providing a comprehensive picture of the time-course of the exposure-outcome relationship cannot use the linear estimators and a non-linear one is appropriate. This method was first developed by Gasparrini and colleagues in 2011(Gasparrini 2011; Gasparrini et al. 2010; Lin et al. 2013b).

3. Studies observing mortality outcomes in all types of CVDs.

4. Those reporting results which included the effect estimate associated with one unit increase or decrease in temperature. An outcome measure was reported as either: relative risk, odds ratio, regression coefficient or percent change.

5. Also, the studies which used the percent change in mortality associated with one unit increase or decrease in the temperature by turning odds ratio with this formula; (OR - 1) $\mathrm{x} 100=$ percent increase

On the other hand, the exclusion criteria were:

1. The studies providing only linear curves of temperature-outcome relationship

2. The studies using indoor temperature as the exposure variable

3. The qualitative studies without precise statistical relationship

4. Studies related to periods of extreme temperature such as the cold spells and heat waves

\section{Data extraction}

The results of titles and abstracts of all relevant studies were merged into the Endnote software, and the duplicates were removed. Abstracts and titles were screened by two independent reviewers and non-relevant articles were deleted. Full-text articles which met the inclusion criteria for the systematic review were downloaded. We were able to obtain full-text papers of all the potentially eligible studies and there was no need to contact their corresponding authors. The results of reviews were then compared and in the case of any discrepancies, they were resolved through consensuses. We tested publication bias using Egger's Method. 


\section{Study Quality Assessment}

83 In order to separate low-quality studies from others, quality assessment was necessary. 84 Assessing the quality of public health studies and their risk of bias may be difficult. This is partly 85 due to the wide variety of study designs used. Assessment of the quality or risk of bias for all of 86 the reviewed studies was conducted by two independent reviewers using the Critical Appraisal 87 Skills Program (CASP).This was adapted from Critical Appraisal Skills Program, Public Health 88 Resource Unit, and Institute of Health Science, Oxford(Oxman et al. 1994). In this checklist, the 89 quality score ranged from 1 to 10 . A cut-off point of 6 was used for any study to be included in 90 this systematic review and meta-analysis. The quality of studies was investigated based on: the 91 study design/time-span; the population of study; sample size; statistical methods; main temperature 92 exposure variable; confounder variables and lag time.

\section{Statistical Analysis}

Statistical analysis was performed in two steps. At first, the pooled effect size was computed for temperature exposure to the cold and hot weather using the random-effects meta-analysis. In the next step, dose-response effects of temperature on cardiovascular mortality were modeled using the random effects meta-regression.

In all of the reviewed studies, the hot and cold effect were calculated separately in six studies using the percent change in mortality associated with one unit increase or decrease of the temperature. The odds ratio (OR) were calculated using this formula; $(\mathrm{OR}-1) \times 100=$ percent increase mortality. Then we converted the ORs to relative risk (RRs) using the following equation: $\mathrm{RR}=\mathrm{OR} /[(1-\mathrm{P} 0)+(\mathrm{P} 0 \times \mathrm{OR})]$, where $\mathrm{P} 0=$ the incidence of non-exposed group. When the value of $\mathrm{P} 0$ is extremely small, we assume $\mathrm{RR}=\mathrm{OR}$.

In a study (Goggins et al. 2013a) the effect of $10{ }^{\circ} \mathrm{C}$ decrease of temperature on cardiovascular mortality was reported. Here, in order to calculate the risk of CVD mortality per $1{ }^{\circ} \mathrm{C}$ decrease of temperature, first, the percent of death due to cardiovascular mortality was changed to the relative risk then this effect size was divided by 10 .

In some studies comparison between several percentiles used for the heat and cold temperature effects on cardiovascular mortality which had a great influence on mortality in our analysis. All the studies provided different lag patterns estimating the exposure-outcome and the delayed effect 
111 of temperature change from a single day to 35 days. In this case, we chose the largest estimate 112 effects.

113 In cases where the results of the temperature effects on mortality in one city observed in two 114 studies were similar, only one study was analyzed. If the outcomes of cardiovascular mortality in 115 the two studies were different, then both included. The pooled effect sizes were calculated 116 separately for the cold and heat temperature. Also, we analyzed pooled effect size based on 117 subgroup for males, females and vulnerable age groups in cold and hot temperature separately.

118 In order to evaluate the city-specific estimates, we calculated the $\mathrm{I}^{2}$ criteria. It was used to 119 investigate heterogeneity between studies, whereby the increasing values (from $0 \%$ to $100 \%$ ) could 120 explain the increasing heterogeneity(Turner et al. 2012). We used the Bayesian hierarchical 121 approach to pool the city-specific effect estimates.

122 At the end, to show the reason of high heterogeneity in the estimated effect sizes, Meta123 regression models were estimated. The dependent variables were the effect sizes (risk of 124 cardiovascular mortality) of cold or heat exposure in each study. The explanatory variables were 125 the mean annual temperature of the location of studies, the number of lag days in each study, 126 latitude, and longitude of the location of studies. The Meta-regression models were estimated using 127 the study variance estimator. All the analyses were conducted using the Stata 12.0 (Stata 128 Corporation, College Station, Texas, USA).

\section{Results}

130 As shown in Figure 1, 681 articles were identified in the initial search. After screening the title 131 and abstract, 626 articles were excluded because of not absolutely full-filling the inclusion criteria.

132 Of the remaining 55 articles, 10 were excluded due to their estimated effect based on extreme 133 event weather such as cold spells and heat waves (Barnett et al. 2012; Chen et al. 2015; Lee et al. 134 2015; Ma et al. 2015; Sheridan \& Lin 2014; Son et al. 2012; Tian et al. 2013; Xie et al. 2013; Zeng 135 et al. 2014; Zhou et al. 2014). Five studies were excluded based on the special meteorological 136 indicators [(diurnal temperature range, (DTR)] (Ding et al. 2015; Yang et al. 2013), [universal

137 thermal climate index (UTCI)](Burkart et al. 2014),[Temperature Changes between Neighboring 138 Days](Lin et al. 2013a) and [Apparent Temperature](Sun et al. 2012).In the eight studies with 
139 case-crossover design using special meteorological indicators (e.g., Apparent Temperature and 140 Tapp $_{\max }$ ) were excluded(Basu \& Ostro 2008; Bell et al. 2008; Gronlund et al. 2015; Madrigano et 141 al. 2013; Medina-Ramón \& Schwartz 2007; Stafoggia et al. 2006; Wichmann et al. 2011; Wilson 142 et al. 2013). Two studies provided the estimates of temperature effect on all- cause mortality, not 143 special cardiovascular mortality(Son et al. 2012; Vutcovici et al. 2014), and one study used the 144 particular effect measure entitled "years of life lost"(Huang et al. 2012). The data of one study on 145 cardiovascular and respiratory mortality were mixed and was not reported separately(Goldberg et 146 al. 2011). Two studies written by the same authors, at the same time, geographical area and with 147 similar information were removed(Breitner et al. 2014b; Yu et al. 2011a). The remaining 26 studies 148 were included in the meta-analysis.

149 Among the included studies, 22 studies assessed effects of both heat and cold on cardiovascular 150 mortality (Bai et al. 2014; Breitner et al. 2014a; Breitner et al. 2014b; Chen et al. 2014; Guo et al. 151 2012a; Guo et al. 2012b; Huang et al. 2014; Huang et al. 2015; Kim et al. 2015; Lin et al. 2013b; 152 Seposo et al. 2015; Tian et al. 2012; Wang et al. 2014; Wang et al. 2015; Wichmann et al. 2013; 153 Yang et al. 2015a; Yang et al. 2012; Yang et al. 2015b; Yang et al. 2015c; Yi \& Chan 2015; Yu et 154 al. 2011b; Yu et al. 2011c). Three studies specifically examined the effect of heat on 155 mortality(Chan et al. 2012; Kim et al. 2016; Qiao et al. 2015b) and two studies examined the cold 156 effects on mortality(Goggins et al. 2013b; Gomez-Acebo et al. 2013). The majority of studies 157 utilized confounding variables such as $\mathrm{PM}_{10}, \mathrm{O}_{3}, \mathrm{NO}_{2}, \mathrm{SO}_{2}$, humidity, atmospheric pressure, time 158 trend and season leading to more reliable estimates of temperature effects on cardiovascular 159 mortality.The day lag in considered studies ranged from 0 to 35 days. This was an important 160 consideration that the effects of temperature on mortality extend beyond one day. The study period 161 of included investigations was from 2 years(Gómez-Acebo et al. 2013) till 31 years (Kim et al. 162 2016). A large number of studies used a specific percentile of temperature to test the presence of 163 the heat and cold effect (Bai et al. 2014; Breitner et al. 2014a; Breitner et al. 2014b; Chen et al. 164 2014; Goggins et al. 2013a; Gomez-Acebo et al. 2013; Guo et al. 2012a; Guo et al. 2012b; Kim et 165 al. 2015; Lin et al. 2013b; Ma et al. 2014; Seposo et al. 2015; Tian et al. 2012; Wang et al. 2014; 166 Wang et al. 2015; Yang et al. 2015a; Yang et al. 2012; Yang et al. 2015b; Yang et al. 2015c; Yi \& 167 Chan 2015). In the remaining studies, the specific heat or cold temperature was used as a starting 168 point (Chan et al. 2012; Huang et al. 2014; Huang et al. 2015; Kim et al. 2016; Qiao et al. 2015b; 169 Yu et al. 2011b; Yu et al. 2011c). In most of the studies, the daily mean temperature was used as 
170 a main temperature exposure variable. In the study where researchers used mean temperatures and

171 diurnal temperature range (DTR) as the thermal index, the mean temperature findings were

172 included in the meta-analysis(Kim et al. 2016). In all of the included studies, 25 had time series

173 design and one study case-crossover design. The final articles included in this analysis are listed

174 in Table 1.In this table, comprehensive details on each study in terms of time, location, the type of

175 heart disease and defined warm and cold temperature are presented.

176 The pooled effect sizes of the short-term effect of temperature exposure and cardiovascular 177 mortality were separately reported for the cold and heat exposure.

The risk of cardiovascular mortality increased by 5\% (RR, 1.055; 95\% CI, 1.050 to 1.060$)$ for the cold exposure, $1.3 \%$ (RR, 1.013; 95\% CI, 1.011 to 1.015) for the heat exposure (figures 2 and 3 ). The short-term effects of cold and heat exposure on risk of cardiovascular mortality in males were $3.8 \%$ (RR, 1.038; 95\% CI, 1.034 to 1.043 ) and $1.1 \%(\mathrm{RR}, 1.011 ; 95 \% \mathrm{CI}, 1.009$ to 1.013 ) respectively (figures 4 and 5).Also effects of cold and heat exposure on risk of cardiovascular mortality in female were $4.1 \%$ (RR, $1.041 ; 95 \%$ CI, 1.037 to 1.045$)$ and $1.4 \%$ (RR, 1.014; $95 \%$ CI, 1.011 to 1.017 ) respectively (figures 6 and 7). In the elderly, these figures raised to $8.1 \%$ and $6 \%$ in the heat exposure and cold exposure respectively (figures 8 and 9 ). The lag days have also an effect on the risk of cardiovascular mortality for the heat and cold exposure so that the greatest risk of cardiovascular mortality in cold temperature was in the 14 lag days (RR, 1.09; 95\% CI, 1.07 to 1.010$)$ and in hot temperature in the 7 lag days (RR, 1.11; 95\% CI, 1.08 to 1.14) (table 2). Regarding the effect of low and high educational level on risk of CVD mortality, similar findings were revealed (table 2 ).

178 The dose-response effects of the mean annual temperature, the number of lag days, latitude 179 and longitude of the location of studies on the risk of cardiovascular mortality are shown in table

180 3. The results showed that the temperature associated increase in risk of cardiovascular mortality 181 increased with each degree increased significantly in latitude and longitude in cold exposure $(0.2 \%$, 182 95\% CI: (0.006-0.035) and (0.07\%, 95\% CI: 0.0003 - 0.014) respectively. The temperature 183 associated increase in risk of cardiovascular mortality increased with each degree increase in 184 latitude in heat exposure $(0.07 \%, 95 \%$ CI: 0.0008 - 0.124). However, this dose-response 185 relationship was not statistically significant in other explanatory variables. For both heat and cold 
186 exposure, $\mathrm{I}^{2}$ values were mostly on the order of $76 \%$ to $92 \%$, indicating large heterogeneity among

187 studies, and emphasizes the use of random-effects models.

188 Discussion

189 To the best of our knowledge, this study is the first meta-analysis to survey the association

190 between temperature and cardiovascular mortality. Also, findings of this study showed that both

191 cold and hot temperatures increased the risk of cardiovascular mortality, although, the cold

192 temperature had stronger effects on CVD mortality. This result is consistent with other

193 investigations that revealed cold weather is responsible for the most part of the temperature-related

194 CVD mortality(Goggins et al. 2013a; Xie et al. 2012; Yang et al. 2015c). In contrast to our

195 findings, Grjibovski et al in a study in Astana, Kazakhstan- the second coldest capital in the world

196 between 2000-2001 and 2006-2010- didn't find any significant associations between ambient

197 temperatures and mortality of hypertensive diseases(ICD-10 codes: I10-I15), ischemic heart

198 disease (I20-I25) and CVDs (I60-I69)(Grjibovski et al. 2012). The inconsistency between the

199 findings may be due to differences in geographical location of studies and weather conditions.

200 The cold seasons causes physiological changes including increases in blood sugar, the level of

201 cholesterol, fibrinogen concentration and platelet aggregation. Fibrinogen plays an important role

202 in the formation of clots in the coronary artery, the start of acute myocardial infarction and life-

203 threatening arrhythmias (Čulić 2007; Mittleman \& Mostofsky 2011). Cold temperature causes

204 peripheral vasoconstriction and increase of cardiac afterload in patients with preexisting CVDs as

205 a result of exacerbating symptoms. Furthermore, cold weather may induce complications such as

206 respiratory infections with an indirect effect on the cardiovascular performance.

207 Our study also indicated that hot exposure increase risk of cardiovascular mortality. In this regard,

208 Qiao et al reported a sensible effect of high temperatures on cardiovascular deaths in summer(Qiao 209 et al. 2015a).

210 Exposure to high temperature could increase the viscosity of plasma and cholesterol levels in

211 serum (Lin et al. 2013b). Also, it has been shown that hot temperature leads to the increase in red

212 blood cell and platelet counts(Bhaskaran et al. 2009). However, further studies are required to

213 identify the accurate mechanisms of heat effect on the CVD mortality. 
214 Our finding showed that both hot and cold temperature had a strong effect on cardiovascular 215 mortality in elderly. In agreement with our finding, Weiwei et al reported that $1^{\circ} \mathrm{C}$ increase in 216 temperature was associated with $2-5 \%$ increase in mortality rate whereas $1^{\circ} \mathrm{C}$ decrease in 217 temperature causes $1-2 \%$ increase in mortality ( $\mathrm{Yu}$ et al. 2012). Ability to regulate the body 218 temperature decreases with age and an elevated sweating threshold. In the hot temperatures, older 219 people may lose body fluids and become dehydrated. They, thus, eventually experience the 220 cardiovascular complications. Moreover, the process of atherosclerosis escalates the conditions for 221 developing CVDs such as ACS.

222 Results of this study showed that the effect of cold and hot temperature on cardiovascular 223 mortality regarding the gender was approximately the same. In this regard, Kan et al indicated that the effect of the cold and heat temperature was not significantly different between the two genders 225 (Kan et al. 2007). However, the findings of Yang et al(Yang et al. 2012) and Lim et al (Lim et al. 2015) showed that men were less sensitive to effects of DTR on cardiovascular mortality and morbidity than women. Conversely, Chen and colleagues reported extreme temperatures were significantly associated with cardiovascular mortality among both males and females, but the associations were stronger for males(Chen et al. 2014).

We noticed that high and low temperature had the greatest effect in lag 7 and 14 respectively. According to the previous studies, the temperature variability had delayed effect on health. The study conducted by Huang et al showed that effect of the cold temperatures had a long lag period of 10-25 days while the hot temperatures had a short lag period of only 1-3 days(Huang et al. 2014). Several recent studies reported that the cold days have a longer lag effect on the cardiovascular morbidity and mortality compared to hot days, (Lin et al. 2013b; Yu et al. 2011b; $\mathrm{Yu}$ et al. 2011c). However, to date, the underlying environmental and physiological mechanisms for various lag effects of heat and cold exposure remain unclear thus more studies are required.

238 Many factors may influence the relationship between ambient temperature and cardiovascular 239 mortality either directly or indirectly as confounders. Our results did not show significant differences in mortality in people with different educational levels in hot and cold weather. In a study, results showed that the level of education and socioeconomic status could also be affecting

242 the relationship between temperature and mortality(Son et al. 2012). The discrepancies between 
243 the findings of this study and others are perhaps due to the paucity of studies in this regard. The 244 people living in low-income countries with poor access to suitable heating or cooling systems 245 much experience the adverse effect of temperature. Also, those with low level of education have 246 been reported more vulnerable to exposure-response relationship.

247

248

249

250

251

252

253

254

255

256

257

258

259

260

261

262

263

264

265

266

267

268

269

270

271

For dose-response relationship between temperature and risk of CVD mortality, one-degree change for latitude significantly increased the risk of mortality. That means higher latitude countries show higher effects of cold temperature on the risk of cardiovascular mortality. Findings of many previous studies showed that extreme cold temperature is a major public health threat in high-latitude countries(Kysely et al. 2009; Shaposhnikov et al. 2014). This study revealed increase in longitude had higher effects of cold temperature in mortality. Differences of longitude may incorporate the different characteristics between cities and nations. Further study is required to assess how characteristics of the cities and nations may modify the temperature effect. Also, a onedegree increase of latitude significantly increased the risk of mortality in heat temperature. This finding is consistent with the previous reviews (Kim et al. 2016). The reasons for the latitude effect in colder weather were that the adaptive capacity of people who live in cold climate is lower because the population is less acclimatized to hot temperatures and live in houses that are improper for hot weather.

This study has several strengths. First, it is the first study to apply a systematic review and meta-analysis in assessing the available and valid literature related to the effects of ambient temperature on cardiovascular mortality. Second, we used the daily mean temperature which is the best indicator to show the exposure - outcome relationship of the cold and heat ambient temperature. In this case, previous studies only showed that the daily mean temperature was the best predictor of the death counts(Anderson \& Bell 2009). Finally, we included the studies with nonlinear models statistical analysis (DLNM). The major advantage of this is that it is flexible enough to simultaneously describe a non-linear exposure-response association and delayed effects or harvesting effect. This method was first developed by Gasparrini and colleagues in 2011(Gasparrini 2011; Gasparrini et al. 2010; Lin et al. 2013b).

However, this study was not exceptional to some limitations. Although an accurate and complete search to select the eligible primary studies was employed, most of the studies reviewed 
272 were from the South East Asian countries such as China and few others from other parts of the

273 world. Lack of attention to the use of air conditioning in summer, heating system in winter and

274 socioeconomic and demographic factors in many primary studies that were considered for this

275 review and analysis is also another likely limitation to the study.

\section{Conclusion}

277 Our systematic review and meta-analysis showed that the ambient temperature is associated

278 with increased cardiovascular mortality rates. According to our findings, the increase and decrease

279 in the ambient temperature had a relationship with the cardiovascular mortality. People with 280 underlying heart disease especially the elderly are more vulnerable to the cold and hot effects. To

281 prevent the temperature- related mortality, people with cardiovascular disease and vulnerable

282 groups especially the elderly should be targeted.

283 Based on the evidence rereviewed most studies were conducted in the South East Asia so future 284 studies are recommended in other parts with a focus on specific geographical and climate areas.

\section{References}

Critical Appraisal Skills Programme: Making Sense of Evidence. Avalable at: http://www.casp-uk.net. Ahmadnezhad E, Holakouie Naieni K, Ardalan A, Mahmoodi M, Yunesian M, Naddafi K, and Mesdaghinia AR. 2013. Excess mortality during heat waves, Tehran Iran: An ecological time-series study. Journal of research in health sciences 13:24-31.

Anderson BG, and Bell ML. 2009. Weather-related mortality: how heat, cold, and heat waves affect mortality in the United States. Epidemiology (Cambridge, Mass) 20:205.

Bai L, Woodward A, and Liu Q. 2014. Temperature and mortality on the roof of the world: a time-series analysis in three Tibetan counties, China. Science of The Total Environment 485:41-48.

Barnett A, Hajat S, Gasparrini A, and Rocklöv J. 2012. Cold and heat waves in the United States. Environmental Research 112:218-224.

Basu R, and Ostro BD. 2008. A multicounty analysis identifying the populations vulnerable to mortality associated with high ambient temperature in California. American journal of epidemiology 168:632-637.

Bell ML, O'Neill MS, Ranjit N, Borja-Aburto VH, Cifuentes LA, and Gouveia NC. 2008. Vulnerability to heat-related mortality in Latin America: a case-crossover study in Sao Paulo, Brazil, Santiago, Chile and Mexico City, Mexico. International journal of epidemiology 37:796-804.

Bhaskaran K, Hajat S, Haines A, Herrett E, Wilkinson P, and Smeeth L. 2009. The effects of ambient temperature on the incidence of myocardial infarction-A systematic review. Heart. 
Breitner S, Wolf K, Devlin RB, Diaz-Sanchez D, Peters A, and Schneider A. 2014a. Short-term effects of air temperature on mortality and effect modification by air pollution in three cities of Bavaria, Germany: a time-series analysis. Science of The Total Environment 485:49-61.

Breitner S, Wolf K, Peters A, and Schneider A. 2014b. Short-term effects of air temperature on causespecific cardiovascular mortality in Bavaria, Germany. Heart 100:1272-1280.

Burkart K, Breitner S, Schneider A, Khan MMH, Krämer A, and Endlicher W. 2014. An analysis of heat effects in different subpopulations of Bangladesh. International journal of biometeorology 58:227-237.

Chan EYY, Goggins WB, Kim JJ, and Griffiths SM. 2012. A study of intracity variation of temperaturerelated mortality and socioeconomic status among the Chinese population in Hong Kong.

Journal of Epidemiology and Community Health 66:322-327.

Chen K, Bi J, Chen J, Chen X, Huang L, and Zhou L. 2015. Influence of heat wave definitions to the added effect of heat waves on daily mortality in Nanjing, China. Science of The Total Environment 506:18-25.

Chen R, Li T, Cai J, Yan M, Zhao Z, and Kan H. 2014. Extreme temperatures and out-of-hospital coronary deaths in six large Chinese cities. Journal of Epidemiology and Community Health:jech-2014204012.

Cheng X, and Su H. 2010. Effects of climatic temperature stress on cardiovascular diseases. European journal of internal medicine 21:164-167.

Čulić V. 2007. Acute risk factors for myocardial infarction. International journal of cardiology 117:260269.

Ding Z, Guo P, Xie F, Chu H, Li K, Pu J, Pang S, Dong H, Liu Y, and Pi F. 2015. Impact of diurnal temperature range on mortality in a high plateau area in southwest China: A time series analysis. Science of The Total Environment 526:358-365.

Gasparrini A. 2011. Distributed lag linear and non-linear models in R: the package dlnm. Journal of Statistical Software 43:1.

Gasparrini A, Armstrong B, and Kenward M. 2010. Distributed lag non-linear models. Statistics in medicine 29:2224.

Goggins WB, Chan E, Yang C, and Chong M. 2013a. Associations between mortality and meteorological and pollutant variables during the cool season in two Asian cities with sub-tropical climates:

Hong Kong and Taipei. Environ Health 12:59.

Goggins WB, Chan EY, Yang C, and Chong M. 2013b. Associations between mortality and meteorological and pollutant variables during the cool season in two Asian cities with sub-tropical climates:

Hong Kong and Taipei. Environ Health 12.

Goldberg MS, Gasparrini A, Armstrong B, and Valois M-F. 2011. The short-term influence of temperature on daily mortality in the temperate climate of Montreal, Canada. Environmental Research

111:853-860.

Gomez-Acebo I, Llorca J, and Dierssen T. 2013. Cold-related mortality due to cardiovascular diseases, respiratory diseases and cancer: a case-crossover study. Public health 127:252-258.

Gómez-Acebo I, Llorca J, and Dierssen T. 2013. Cold-related mortality due to cardiovascular diseases, respiratory diseases and cancer: a case-crossover study. Public health 127:252-258.

Grjibovski AM, Nurgaliyeva N, Kosbayeva A, and Menne B. 2012. No association between temperature and deaths from cardiovascular and cerebrovascular diseases during the cold season in Astana, Kazakhstan-the second coldest capital in the world. International journal of circumpolar health 71.

Gronlund CJ, Berrocal VJ, White-Newsome JL, Conlon KC, and O'Neill MS. 2015. Vulnerability to extreme heat by socio-demographic characteristics and area green space among the elderly in Michigan, 1990-2007. Environmental Research 136:449-461. 
Guo Y, Li S, Zhang Y, Armstrong B, Jaakkola JJ, Tong S, and Pan X. 2012a. Extremely cold and hot temperatures increase the risk of ischaemic heart disease mortality: epidemiological evidence from China. Heart:heartjnl-2012-302518.

Guo Y, Punnasiri K, Tong S, Aydin D, and Feychting M. 2012b. Effects of temperature on mortality in Chiang Mai city, Thailand: a time series study. Environ Health 11:10.1186.

Habib RR, El Zein K, and Ghanawi J. 2010. Climate change and health research in the Eastern Mediterranean Region. EcoHealth 7:156-175.

Huang C, Barnett AG, Wang X, and Tong S. 2012. Effects of extreme temperatures on years of life lost for cardiovascular deaths: a time series study in Brisbane, Australia. Circulation: Cardiovascular Quality and Outcomes 5:609-614.

Huang J, Wang J, and Yu W. 2014. The lag effects and vulnerabilities of temperature effects on cardiovascular disease mortality in a subtropical climate zone in China. International journal of environmental research and public health 11:3982-3994.

Huang Z, Lin H, Liu Y, Zhou M, Liu T, Xiao J, Zeng W, Li X, Zhang Y, and Ebi KL. 2015. Individual-level and community-level effect modifiers of the temperature-mortality relationship in 66 Chinese communities. BMJ open 5:e009172.

Kan H, London SJ, Chen H, Song G, Chen G, Jiang L, Zhao N, Zhang Y, and Chen B. 2007. Diurnal temperature range and daily mortality in Shanghai, China. Environmental Research 103:424-431. Kim H, Heo J, Kim H, and Lee J-T. 2015. Has the impact of temperature on mortality really decreased over time? Science of The Total Environment 512:74-81.

Kim J, Shin J, Lim Y-H, Honda Y, Hashizume M, Guo YL, Kan H, Yi S, and Kim H. 2016. Comprehensive approach to understand the association between diurnal temperature range and mortality in East Asia. Science of The Total Environment 539:313-321.

Kysely J, Pokorna L, Kyncl J, and Kriz B. 2009. Excess cardiovascular mortality associated with cold spells in the Czech Republic. BMC public health 9:19.

Lee WK, Lee HA, Lim YH, and Park H. 2015. Added effect of heat wave on mortality in Seoul, Korea. International journal of biometeorology:1-8.

Li Y, Du T, Lewin MR, Wang H, Ji X, Zhang Y, Xu T, Xu L, and Wu JS. 2011. The seasonality of acute coronary syndrome and its relations with climatic parameters. The American journal of emergency medicine 29:768-774.

Lim Y-H, Reid CE, Mann JK, Jerrett M, and Kim H. 2015. Diurnal temperature range and short-term mortality in large US communities. International journal of biometeorology 59:1311-1319.

10.1007/s00484-014-0941-2

Lin H, Zhang Y, Xu Y, Xu X, Liu T, Luo Y, Xiao J, Wu W, and Ma W. 2013a. Temperature changes between neighboring days and mortality in summer: a distributed lag non-linear time series analysis. PLoS one 8:e66403.

Lin Y-K, Chang C-K, Wang Y-C, and Ho T-J. 2013b. Acute and Prolonged Adverse Effects of Temperature on Mortality from Cardiovascular Diseases. PLoS one 8:e82678.

Ma W, Chen R, and Kan H. 2014. Temperature-related mortality in 17 large Chinese cities: How heat and cold affect mortality in China. Environmental Research 134:127-133.

Ma W, Zeng W, Zhou M, Wang L, Rutherford S, Lin H, Liu T, Zhang Y, Xiao J, and Zhang Y. 2015. The short-term effect of heat waves on mortality and its modifiers in China: An analysis from 66 communities. Environment international 75:103-109.

Madrigano J, Mittleman MA, Baccarelli A, Goldberg R, Melly S, Von Klot S, and Schwartz J. 2013. Temperature, myocardial infarction, and mortality: effect modification by individual and arealevel characteristics. Epidemiology (Cambridge, Mass) 24:439. 
Medina-Ramón M, and Schwartz J. 2007. Temperature, temperature extremes, and mortality: a study of acclimatisation and effect modification in 50 US cities. Occupational and environmental medicine 64:827-833.

Mittleman MA, and Mostofsky E. 2011. Physical, Psychological and Chemical Triggers of Acute Cardiovascular Events Preventive Strategies. Circulation 124:346-354.

Ng CFS, Ueda K, Takeuchi A, Nitta H, Konishi S, Bagrowicz R, Watanabe C, and Takami A. 2014. Sociogeographic Variation in the Effects of Heat and Cold on Daily Mortality in Japan. Journal of Epidemiology 24:15.

Oxman AD, Cook DJ, Guyatt GH, Bass E, Brill-Edwards P, Browman G, Detsky A, Farkouh M, Gerstein H, and Haines T. 1994. Users' guides to the medical literature: VI. How to use an overview. Jama 272:1367-1371.

Pfeiffer AJ. 2011. The Effects of Climate Change on Public Health and the Healthcare Provider's Role in Addressing Climate Change.

Qiao Z, Guo Y, Yu W, and Tong S. 2015a. Assessment of Short- and Long-Term Mortality Displacement in Heat-Related Deaths in Brisbane, Australia, 1996-2004. Environmental Health Perspectives

123:766-772. 10.1289/ehp.1307606

Qiao Z, Guo Y, Yu W, and Tong S. 2015b. Assessment of short-and long-term mortality displacement in heat-related deaths in Brisbane, Australia, 1996-2004. Environmental Health Perspectives

123:766.

Rocklöv J, Kristie E, and Bertil F. 2010. Mortality related to temperature and persistent extreme temperatures: a study of cause-specific and age-stratified mortality. Occupational and environmental medicine:oem. 2010.058818.

Ryti NR, Guo Y, and Jaakkola J. 2015. Global association of cold spells and adverse health effects: a systematic review and meta-analysis. Environ Health Perspect.

Seposo XT, Dang TN, and Honda Y. 2015. Evaluating the effects of temperature on mortality in manila city (Philippines) from 2006-2010 using a distributed lag nonlinear model. International journal of environmental research and public health 12:6842-6857.

Shaposhnikov D, Revich B, Gurfinkel Y, and Naumova E. 2014. The influence of meteorological and geomagnetic factors on acute myocardial infarction and brain stroke in Moscow, Russia.

International journal of biometeorology 58:799-808.

Sheridan SC, and Lin S. 2014. Assessing variability in the impacts of heat on health outcomes in New York city over time, season, and heat-wave duration. EcoHealth 11:512-525.

Shonkoff SB. 2012. Climate Change Mitigation: Climate, Health, and Equity Implications of the Visible and the Hidden.

Son J-Y, Lee J-T, Anderson GB, and Bell ML. 2012. The impact of heat waves on mortality in seven major cities in Korea. Environmental Health Perspectives 120:566.

Stafoggia M, Forastiere F, Agostini D, Biggeri A, Bisanti L, Cadum E, Caranci N, de'Donato F, De Lisio S, and De Maria M. 2006. Vulnerability to heat-related mortality: a multicity, population-based, case-crossover analysis. Epidemiology 17:315-323.

Sun J, Li GX, Jayasinghe R, Sadler R, Shaw G, and Pan XC. 2012. Time course of apparent temperature effects on cardiovascular mortality: a comparative study of Beijing, China and Brisbane,

Australia. Public Health Research 2:43-48.

Tian Z, Li S, Zhang J, and Guo Y. 2013. The characteristic of heat wave effects on coronary heart disease mortality in Beijing, China: a time series study. PLoS one 8:e77321.

Tian Z, Li S, Zhang J, Jaakkola JJ, and Guo Y. 2012. Ambient temperature and coronary heart disease mortality in Beijing, China: a time series study. Environ Health 11:10.1186.

Turner LR, Barnett AG, Connell D, and Tong S. 2012. Ambient temperature and cardiorespiratory morbidity: a systematic review and meta-analysis. Epidemiology 23:594-606. 
Vutcovici M, Goldberg MS, and Valois M-F. 2014. Effects of diurnal variations in temperature on nonaccidental mortality among the elderly population of Montreal, Quebec, 1984-2007.

International journal of biometeorology 58:843-852.

Wang C, Chen R, Kuang X, Duan X, and Kan H. 2014. Temperature and daily mortality in Suzhou, China: a time series analysis. Science of The Total Environment 466:985-990.

Wang X, Li G, Liu L, Westerdahl D, Jin X, and Pan X. 2015. Effects of Extreme Temperatures on CauseSpecific Cardiovascular Mortality in China. International journal of environmental research and public health 12:16136-16156.

Wichmann J, Andersen Z, Ketzel M, Ellermann T, and Loft S. 2011. Apparent temperature and causespecific mortality in Copenhagen, Denmark: A case-crossover analysis. International journal of environmental research and public health 8:3712-3727.

Wichmann J, Rosengren A, Sjöberg K, Barregard L, and Sallsten G. 2013. Association between ambient temperature and acute myocardial infarction hospitalisations in Gothenburg, Sweden: 19852010. PLoS one 8:e62059.

Wilson LA, Morgan GG, Hanigan IC, Johnston FH, Abu-Rayya H, Broome R, Gaskin C, and Jalaludin B. 2013. The impact of heat on mortality and morbidity in the Greater Metropolitan Sydney Region: a case crossover analysis. Environmental Health 12:1.

Xie H, Yao Z, Zhang Y, Xu Y, Xu X, Liu T, Lin H, Lao X, Rutherford S, and Chu C. 2012. Short-term effects of the 2008 cold spell on mortality in three subtropical cities in Guangdong Province, China.

Environmental Health Perspectives 121:210-216.

Xie H, Yao Z, Zhang Y, Xu Y, Xu X, Liu T, Lin H, Lao X, Rutherford S, and Chu C. 2013. Short-term effects of the 2008 cold spell on mortality in three subtropical cities in Guangdong Province, China.

Environmental Health Perspectives (Online) 121:210.

Yang C, Meng X, Chen R, Cai J, Zhao Z, Wan Y, and Kan H. 2015a. Long-term variations in the association between ambient temperature and daily cardiovascular mortality in Shanghai, China. Science of The Total Environment 538:524-530.

Yang J, Liu H-Z, Ou C-Q, Lin G-Z, Zhou Q, Shen G-C, Chen P-Y, and Guo Y. 2013. Global climate change: impact of diurnal temperature range on mortality in Guangzhou, China. Environmental Pollution 175:131-136.

Yang J, Ou C-Q, Ding Y, Zhou Y-X, and Chen P-Y. 2012. Daily temperature and mortality: a study of distributed lag non-linear effect and effect modification in Guangzhou. Environ Health 11:63.

Yang J, Ou C-Q, Guo Y, Li L, Guo C, Chen P-Y, Lin H-L, and Liu Q-Y. 2015b. The burden of ambient temperature on years of life lost in Guangzhou, China. Scientific reports 5.

Yang J, Yin P, Zhou M, Ou C-Q, Guo Y, Gasparrini A, Liu Y, Yue Y, Gu S, and Sang S. 2015c. Cardiovascular mortality risk attributable to ambient temperature in China. Heart:heartjnl-2015-308062.

Yi W, and Chan AP. 2015. Effects of temperature on mortality in Hong Kong: a time series analysis. International journal of biometeorology 59:927-936.

Yu W, Guo Y, Ye X, Wang X, Huang C, Pan X, and Tong S. 2011a. The effect of various temperature indicators on different mortality categories in a subtropical city of Brisbane, Australia. Science of The Total Environment 409:3431-3437.

Yu W, Hu W, Mengersen K, Guo Y, Pan X, Connell D, and Tong S. 2011b. Time course of temperature effects on cardiovascular mortality in Brisbane, Australia. Heart 97:1089-1093.

Yu W, Mengersen K, Hu W, Guo Y, Pan X, and Tong S. 2011c. Assessing the relationship between global warming and mortality: lag effects of temperature fluctuations by age and mortality categories.

Environmental Pollution 159:1789-1793.

Yu W, Mengersen K, Wang X, Ye X, Guo Y, Pan X, and Tong S. 2012. Daily average temperature and mortality among the elderly: a meta-analysis and systematic review of epidemiological evidence. International journal of biometeorology 56:569-581. 
Zeng W, Lao X, Rutherford S, Xu Y, Xu X, Lin H, Liu T, Luo Y, Xiao J, and Hu M. 2014. The effect of heat waves on mortality and effect modifiers in four communities of Guangdong Province, China. Science of The Total Environment 482:214-221.

Zhou MG, Wang L, Liu T, Zhang YH, Lin HL, Luo Y, Xiao JP, Zeng WL, Zhang YW, and Wang XF. 2014. Health impact of the 2008 cold spell on mortality in subtropical China: the climate and health impact national assessment study (CHINAs). Environmental Health 13:60. 


\section{Figure 1}

\section{Figure 1. Procedure for literature search}

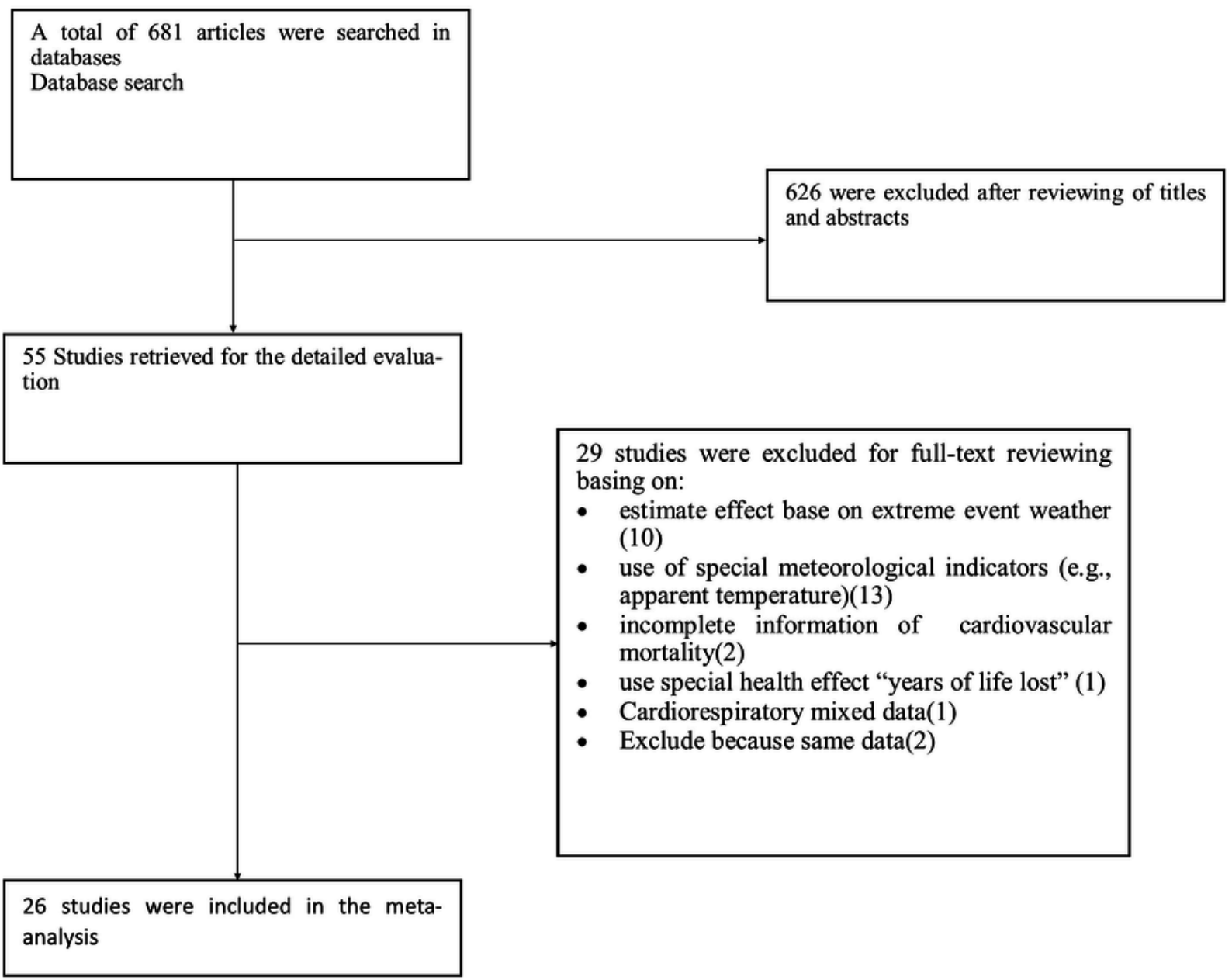




\section{Figure 2}

Figure 2. Meta-analysis of ambient temperature on risk of cardiovascular mortality in cold exposure

Study

ID

Lin et al (2013)

Tian et al (2012)

Yu et al (2011)

Goggins et al (2011)

Goggins et al (2011)

Jun et al (2015)

Yang et al (2012)

Gui et al (2012)

Yi et al (2015)

Seposo et al (2015)

Chen et al (2014)

Gui et al (2012)

Gui et al (2012)

Gui et al (2012)

Gui et al (2012)

Gui et al (2012)

Kim et al (2015)

Huang et al (2015)

Yang et al (2015)

Breitner et al (2014)

Breitner et al (2014)

Breitner et al (2014)

Wang et al (2014)

Ma et al (2014)

Yang et al (2015)

Huang et al (2014)

Yu et al (2011)

Wang et al (2015)

Wang et al (2015)

Bai et al (2014)

Bai et al (2014)

Bai et al (2014)

Gomez-Aceboi et al (2013)

Overall (1-squared $=92.1 \%, p=0.000$ )
ES $(95 \%$

Weight

$2.04(1.61,2.58) \quad 0.01$

$1.16(1.04,1.30) \quad 0.15$

$1.03(1.01,1.06) \quad 3.95$

$1.06(1.04,1.07) \quad 14.09$

$1.06(1.05,1.09) \quad 7.12$

$1.16(1.13,1.18) \quad 4.11$

$1.24(1.11,1.35) \quad 0.18$

$1.45(1.04,2.02) \quad 0.01$

$1.56(1.05,2.14) \quad 0.01$

$1.32(0.87,2.01) \quad 0.01$

$1.49(1.26,1.76) \quad 0.04$

$1.42(1.11,1.81) \quad 0.02$

$1.39(1.18,1.64) \quad 0.05$

$1.65(1.20,2.28) \quad 0.01$

$1.59(1.25,2.03) \quad 0.02$

$1.89(1.43,2.50) \quad 0.01$

$1.00(0.81,1.01) \quad 0.25$

$1.04(1.03,1.05) \quad 40.14$

$1.99(1.85,2.14) \quad 0.12$

$1.10(1.05,1.16) \quad 0.85$

$1.02(0.95,1.09) \quad 0.52$

$1.11(1.01,1.21) \quad 0.26$

$2.67(1.64,4.33) \quad 0.00$

$3.27(1.83,4.27) \quad 0.00$

$1.04(1.03,1.06) \quad 11.42$

$1.07(1.05,1.08) \quad 11.42$

$1.03(1.00,1.05) \quad 4.86$

$1.35(1.24,1.46) \quad 0.21$

$1.14(1.02,1.27) \quad 0.16$

$1.62(0.74,3.55) \quad 0.00$

$1.89(1.08,3.63) \quad 0.00$

$3.68(0.92,7.72) \quad 0.00$

$2.63(1.88,3.67) \quad 0.00$

$1.05(1.05,1.06) \quad 100.00$ 


\section{Figure 3}

Figure 3. Meta-analysis of ambient temperature on risk of cardiovascular mortality in heat exposure

Study

ID

Lin et al (2013)

Tian et al (2012)

Yu et al (2011)

Qiao et al (2011)

Jun et al (2015)

Kim et al (2015)

Yang et al (2012)

Gui et al (2012)

Yi et al (2015)

Seposo et al (2015)

Chen et al (2014)

Gui et al (2012)

Gui et al (2012)

Gui et al (2012)

Gui et al (2012)

Gui et al (2012)

Kim et al (2015)

Huang et al (2015)

Yang et al (2015)

Breitner et al (2014)

Breitner et al (2014)

Breitner et al (2014)

Wang et al (2014)

Ma et al (2014)

Yang et al (2015)

Huang et al (2014)

Yu et al (2011)

Chen et al (2012)

Wang et al (2015)

Wang et al (2015)

Bai et al (2014)

Bai et al (2014)

Bai et al (2014)

Overall (l-squared $=88.9 \%, p=0.000$ )
ES $(95 \% \mathrm{Cl}) \quad$ Weight

$1.22(1.02,1.46) \quad 0.01$

$1.38(1.20,1.60) \quad 0.01$

$1.06(1.03,1.08) \quad 0.45$

$1.22(1.16,1.29) \quad 0.07$

$1.01(1.01,1.01) \quad 45.48$

$1.00(0.99,1.00) \quad 6.73$

$1.21(1.12,1.30) \quad 0.04$

$1.12(0.94,1.33) \quad 0.01$

$1.08(0.98,1.23) \quad 0.02$

$1.37(1.07,1.75) \quad 0.00$

$1.53(1.27,1.84) \quad 0.00$

$1.25(1.00,1.55) \quad 0.00$

$1.32(1.07,1.62) \quad 0.00$

$1.04(0.83,1.31) \quad 0.00$

$1.59(1.16,2.18) \quad 0.00$

$1.34(1.06,1.70) \quad 0.00$

$1.12(1.03,1.21) \quad 0.04$

$1.01(1.01,1.01) \quad 45.48$

$1.16(1.11,1.21) \quad 0.11$

$1.09(1.05,1.13) \quad 0.18$

$1.16(1.10,1.22) \quad 0.08$

$1.06(1.00,1.12) \quad 0.08$

$1.82(1.53,2.16) \quad 0.00$

$3.02(1.33,4.71) \quad 0.00$

$1.04(1.02,1.07) \quad 0.45$

$1.05(1.02,1.08) \quad 0.32$

$1.03(1.00,1.07) \quad 0.29$

$1.02(1.01,1.16) \quad 0.05$

$1.18(1.11,1.25) \quad 0.06$

$1.10(0.99,1.20) \quad 0.03$

$0.73(0.47,0.98) \quad 0.00$

$1.31(0.82,2.10) \quad 0.00$

$2.32(1.03,5.24) \quad 0.00$

$1.01(1.01,1.01) \quad 100.00$ 


\section{Figure 4}

Figure 4. Meta-analysis of cold exposure and risk of cardiovascular mortality in males

Study

ID

Tian et al (2012)

Goggins et al (2011)

Goggins et al (2011)

Jun et al (2015)

Yang et al (2012)

Seposo et al (2015)

Chen et al (2014)

Huang et al (2015)

Wang et al (2014)

Yang et al (2015)

Huang et al (2014)

Bai et al (2014)

Bai et al (2014)

Bai et al (2014)

Gomez-Aceboi et al (2013)

Overall (I-squared $=90.6 \%, p=0.000$ )
$\%$

ES $(95 \% \mathrm{Cl}) \quad$ Weight
$1.15(0.95,1.39) \quad 0.03$

$1.04(1.03,1.06) \quad 9.98$

$1.04(1.03,1.05) \quad 11.88$

$1.16(1.13,1.18) \quad 2.30$

$1.31(1.20,1.42) \quad 0.12$

$0.92(0.80,1.06) \quad 0.09$

$1.69(1.15,2.48) \quad 0.00$

$1.03(1.03,1.04) \quad 71.00$

$1.63(1.26,2.10) \quad 0.01$

$1.05(1.03,1.07) \quad 3.59$

$1.05(1.01,1.08) \quad 0.99$

$1.46(0.94,2.26) \quad 0.00$

$1.13(0.69,2.15) \quad 0.00$

$2.92(1.05,8.63) \quad 0.00$

$3.90(2.51,6.06) \quad 0.00$

$1.04(1.03,1.04) \quad 100.00$ 
Figure 5

Figure 5. Meta-analysis of heat exposure and risk of cardiovascular mortality in males

Study

ID

Tian et al (2012)

Jun et al (2015)

Yang et al (2012)

Seposo et al (2015)

Chen et al (2014)

Huang et al (2015)

Wang et al (2014)

Yang et al (2015)

Huang et al (2014)

Chan et al (2012)

Bai et al (2014)

Bai et al (2014)

Bai et al (2014)

Overall (l-squared $=81.2 \%, p=0.000)$
$\mathrm{ES}(95 \% \mathrm{Cl})$

$\%$

Weight

$1.37(1.16,1.62) \quad 0.01$

$1.01(1.01,1.01) \quad 49.64$

$1.08(1.02,1.14) \quad 0.08$

$1.24(1.13,1.37) \quad 0.02$

$1.73(1.28,2.32) \quad 0.00$

$1.01(1.01,1.01) \quad 49.64$

$1.33(1.14,1.56) \quad 0.01$

$1.03(0.99,1.06) \quad 0.25$

$1.04(1.00,1.08) \quad 0.20$

$1.04(1.00,1.09) \quad 0.15$

$1.14(0.85,1.53) \quad 0.00$

$1.67(1.11,2.52) \quad 0.00$

$1.92(1.05,3.52) \quad 0.00$

$1.01(1.01,1.01) \quad 100.00$ 
Figure 6

Figure 6. Meta-analysis of cold exposure and risk of cardiovascular mortality in females

Study

ID

Tian et al (2012)

Goggins et al (2013)

Goggins et al (2013)

Jun et al (2015)

Yang et al (2012)

Seposo et al (2015)

Chen et al (2014)

Huang et al (2015)

Wang et al (2014)

Yang et al (2015)

Huang et al (2014)

Bai et al (2014)

Bai et al (2014)

Bai et al (2014)

Gomez-Aceboi et al (2013)

Overall $(1$-squared $=88.4 \%, p=0.000)$
ES $(95 \% \mathrm{Cl})$

$\%$

Weight

$1.18(1.03,1.43) \quad 0.04$

$1.05(1.04,1.06) \quad 17.95$

$1.03(1.02,1.05) \quad 6.74$

$1.15(1.13,1.18) \quad 2.59$

$1.16(1.05,1.28) \quad 0.12$

$1.05(0.82,1.35) \quad 0.02$

$1.52(1.00,2.30) \quad 0.00$

$1.03(1.03,1.04) \quad 64.79$

$1.74(1.32,2.29) \quad 0.01$

$1.03(1.01,1.05) \quad 4.05$

$1.07(1.05,1.09) \quad 3.67$

$1.47(0.68,3.17) \quad 0.00$

$1.31(0.76,2.25) \quad 0.00$

$2.34(0.77,7.14) \quad 0.00$

$5.09(3.15,8.21) \quad 0.00$

$1.04(1.04,1.05) \quad 100.00$ 
Figure 7

Figure 7. Meta-analysis of heat exposure and risk of cardiovascular mortality in females

Study

ID

Tian et al (2012)

Yang et al (2012)

Seposo et al (2015)

Chen et al (2014)

Huang et al (2015)

Wang et al (2014)

Yang et al (2015)

Yang et al (2015)

Chan et al (2012)

Bai et al (2014)

Bai et al (2014)

Bai et al (2014)

Overall $(1-$ squared $=90.4 \%, p=0.000)$
$\mathrm{ES}(95 \% \mathrm{Cl})$

$\%$

Weight

$1.42(1.11,1.82) \quad 0.01$

$1.25(1.16,1.33) \quad 0.12$

$1.47(1.27,1.69) \quad 0.02$

$1.48(1.09,1.99) \quad 0.00$

$1.01(1.01,1.02) \quad 98.30$

$1.39(1.17,1.46) \quad 0.04$

$1.06(1.02,1.09) \quad 0.72$

$1.06(1.02,1.11) \quad 0.44$

$1.07(1.02,1.12) \quad 0.33$

$1.02(0.71,1.47) \quad 0.01$

$0.34(0.15,0.80) \quad 0.01$

$1.43(0.75,2.70) \quad 0.00$

$1.01(1.01,1.02) \quad 100.00$ 
Figure 8

Figure 8. Meta-analysis of heat exposure on risk of cardiovascular mortality in vulnerable age groups

Study

ID

$\mathrm{ES}(95 \% \mathrm{Cl})$

$\%$

Tian et al (2012)

Yu et al (2011)

Qiao et al (2015)

Jun et al (2015)

Yang et al (2012)

Gue et al (2012)

Yi et al (2015)

Seposo et al (2015)

Chen et al (2014)

Huang et al (2015)

Wang et al (2014)

Yang et al (2015)

Huang et al (2015)

Yu et al (2011)

Chen et al (2014)

Bai et al (2014)

Bai et al (2014)

Bai et al (2014)

Overall (l-squared $=76.9 \%, p=0.000$ )




Figure 9

Figure 9. Meta-analysis of cold exposure on risk of cardiovascular mortality in vulnerable age groups

Study

ID

Tian et al (2012)

Yu et al (2011)

Goggins et al (2011)

Goggins et al (2011)

Jun et al (2015)

Yang et al (2012)

Gui et al (2012)

Yi et al (2015)

Seposo et al (2015)

Chen et al (2014)

Huang et al (2015)

Wang et al (2014)

Yang et al (2015)

Huang et al (2014)

Yu et al (2011)

Bai et al (2014)

Bai et al (2014)

Bai et al (2014)

Gomez-Aceboi et al (2013)

Overall (I-squared $=92.3 \%, p=0.000$ )

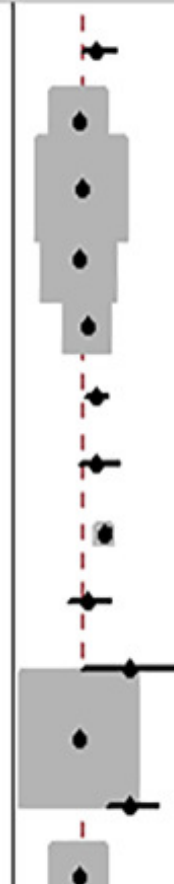

-

-
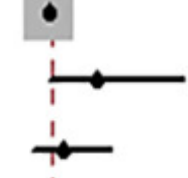

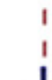

$\begin{array}{ll}\% & \% \\ \text { ES }(95 \% \mathrm{Cl}) & \text { Weight }\end{array}$

$1.29(1.06,1.58) \quad 0.05$

$1.04(1.02,1.06) \quad 7.87$

$1.07(1.06,1.09) \quad 19.57$

$1.04(1.02,1.05) \quad 12.15$

$1.16(1.13,1.18) \quad 5.29$

$1.29(1.11,1.46) \quad 0.11$

$1.30(1.05,1.61) \quad 0.04$

$1.41(1.35,1.51) \quad 0.52$

$1.14(0.87,1.50) \quad 0.03$

$1.81(1.06,2.56) \quad 0.01$

$1.04(1.03,1.05) \quad 33.08$

$1.80(1.45,2.24) \quad 0.02$

$1.04(1.02,1.06) \quad 8.27$

$1.07(1.05,1.09) \quad 8.27$

$1.03(1.01,1.06) \quad 4.71$

$1.77(1.04,3.10) \quad 0.00$

$1.24(0.78,1.97) \quad 0.01$

$4.03(1.06,7.15) \quad 0.00$

$3.80(2.83,5.09) \quad 0.00$

$1.06(1.05,1.06) \quad 100.00$ 
Table $\mathbf{1}$ (on next page)

Characteristic of included studies 


\begin{tabular}{|c|c|c|c|c|c|c|c|c|c|}
\hline NO & $\begin{array}{l}\text { Authors and } \\
\text { Years of } \\
\text { publication }\end{array}$ & Events No /Data source & $\begin{array}{l}\text { Location and } \\
\text { time period }\end{array}$ & $\begin{array}{l}\text { Main temperature } \\
\text { exposure } \\
\text { variable(s) }\end{array}$ & $\begin{array}{l}\text { Variables } \\
\text { Controlled }\end{array}$ & $\begin{array}{l}\text { Lags } \\
\text { (Days) }\end{array}$ & Study Design & $\begin{array}{c}\text { Effect estimate of } \\
\text { temperature/threshold } \\
\text { (definition of hot \&cold } \\
\text { effect) }\end{array}$ & $\begin{array}{c}\text { Outcome } \\
\text { measurement }\end{array}$ \\
\hline 1 & $\begin{array}{l}\text { Lin et al } \\
\text { 2013 (Lin et al. } \\
\text { 2013) }\end{array}$ & $\begin{array}{l}\text { 1.25-3.75 mortality per day } \\
\text { department of Health }\end{array}$ & $\begin{array}{l}\text { four regions of } \\
\text { Taiwan } \\
1994-2007\end{array}$ & Mean temperature & $\mathrm{PM}^{1} 10, \mathrm{NO}_{x}^{2}, \mathrm{O}^{3} 3$ & $0-20$ & Time-Series & $\begin{array}{l}15^{\circ} \mathrm{C} \text { compare with } 27^{\circ} \mathrm{C} \text { for } \\
\text { cold effect vs. } 31^{\circ} \mathrm{C} \text { compare } \\
\text { with } 27^{\circ} \mathrm{C} \text { for hot effect }\end{array}$ & $\begin{array}{l}\text { ICD }{ }^{4}-9 \text { Codes } \\
\text { Ischemic heart } \\
\text { disease and CVD }\end{array}$ \\
\hline 2 & $\begin{array}{l}\text { Tian et al } \\
\text { 2012(Tian et al. } \\
\text { 2012) }\end{array}$ & $\begin{array}{l}\text { 26460/ Death Classification } \\
\text { System, Beijing Public Security } \\
\text { Bureau }\end{array}$ & $\begin{array}{l}\text { Beijing, China } \\
\text { 2000-2011 }\end{array}$ & $\begin{array}{l}\text { daily mean } \\
\text { temperature }\end{array}$ & Day of the week & $0-15$ & Time-Series & $\begin{array}{l}\text { 99th }\left(30.5^{\circ} \mathrm{C}\right) \text { compare } 90 \text { th } \\
\left(27.0^{\circ} \mathrm{C}\right) \text { for hot effect vs } 1 \mathrm{st} \\
\left(-7.6^{\circ} \mathrm{C}\right) \text { compare to } 10 \text { th } \\
\left(-2.2^{\circ} \mathrm{C}\right) \text { for cold effect }\end{array}$ & $\begin{array}{l}\text { ICD-10:( I20-I25). } \\
\text { CHD mortality }\end{array}$ \\
\hline 3 & $\begin{array}{l}\text { Yu et al } \\
\text { 2011(Yu et al. } \\
\text { 2011b) }\end{array}$ & $\begin{array}{l}22805 / \text { Office of Economic } \\
\text { and Statistical Research } \\
\text { of the Queensland Treasury }\end{array}$ & $\begin{array}{l}\text { Queensland, } \\
\text { Australia } \\
\text { 1996-2004 }\end{array}$ & mean temperature & $\begin{array}{l}\text { Time trend, } \mathrm{PM}_{10} \\
\mathrm{RH}^{5}, \mathrm{NO}_{2}, \mathrm{O}_{3}\end{array}$ & $0-20$ & Time-Series & $\begin{array}{l}1{ }^{\circ} \mathrm{C} \text { above } 24^{\circ} \mathrm{C} \text { for hot } \\
\text { effect } \\
1{ }^{\circ} \mathrm{C} \text { below } 24^{\circ} \mathrm{C} \text { for cold } \\
\text { effect }\end{array}$ & $\begin{array}{l}\text { ICD-9 :(390-459) } \\
\text { ICD-10( I00-I79) } \\
\text { CVD }\end{array}$ \\
\hline 4 & $\begin{array}{l}\text { Qiao et al } \\
2015 \text { (Qiao et al. } \\
2015 \text { ) }\end{array}$ & $\begin{array}{l}\text { 22,561/ Office of Economic and } \\
\text { Statistical Research of the } \\
\text { Queensland Treasury }\end{array}$ & $\begin{array}{l}\text { Brisbane, Australia } \\
\text { 1996-2004 }\end{array}$ & $\begin{array}{l}\text { daily mean } \\
\text { temperature }\end{array}$ & $\begin{array}{l}\text { Time trend, } \\
\text { seasonality }\end{array}$ & $0-20$ & Time-Series & $\begin{array}{l}1^{\circ} \mathrm{C} \text { mean temperature } \\
\text { increase above the threshold } \\
\left(28^{\circ} \mathrm{C}\right)\end{array}$ & $\begin{array}{l}\text { ICD-9 }:(390-459) \\
\text { ICD-10(I00-I99) } \\
\text { CVD }\end{array}$ \\
\hline 5 & $\begin{array}{l}\text { Goggins et al } \\
2013 \text { (Goggins et } \\
\text { al. 2013) }\end{array}$ & $\begin{array}{l}\text { Hong Kong } 91 / \mathrm{d} \text { and Taiwan } \\
\text { 33/d } \\
\text { Hong Kong Census and Statistics } \\
\text { Bureau, Taiwan's Department of } \\
\text { Health }\end{array}$ & $\begin{array}{l}\text { Hong Kong 19999- } \\
2009 \\
\text { Taiwan 1999-2008 }\end{array}$ & Mean temperature & $\begin{array}{l}\mathrm{RH}, \mathrm{PM}_{10}, \mathrm{NO}_{2}, \\
\mathrm{SO}^{6}, \mathrm{O} 3 \text { wind } \\
\text { speed, solar } \\
\text { radiation, Time } \\
\text { trend, seasonality, } \\
\text { Day of Week }\end{array}$ & $0-35$ & Time-Series & $\begin{array}{l}10 \mathrm{C} \text { drop in temperature in } \\
\text { cold seson for Cold effect }\end{array}$ & $\begin{array}{l}\text { ICD-9 :(390-459) } \\
\text { ICD-10(I00-199) }\end{array}$ \\
\hline 6 & $\begin{array}{l}\text { Jun et al } \\
2015 \text { (Yang et al. } \\
2015 \text { c) }\end{array}$ & $\begin{array}{l}1936 \text { 116/ Death Register and } \\
\text { Report of Chinese } \mathrm{CDC}^{7}\end{array}$ & $\begin{array}{l}\text { China 2007-2013 } \\
\text { 2007- } 2013\end{array}$ & Mean temperature & not mention & $0-21$ & Time-Series & $\begin{array}{l}\text { 99th compare with MMT for } \\
\text { hot effect vs1th compare with } \\
\text { MMT for cold effect }\end{array}$ & ICD-10(I00-I99) \\
\hline
\end{tabular}

1-PM: Particle Matter

${ }^{2}$-NOx: Nitrous Oxide

${ }^{3}-\mathrm{O}_{3}$ : Ozone

4-ICD: International Classification of Diseases

5-RH: Relative Humidity

${ }^{6}-\mathrm{SO}_{2}$ : Sulfur Dioxide

7. CDC: Center of control Diseases 


\begin{tabular}{|c|c|c|c|c|c|c|c|c|c|}
\hline 7 & $\begin{array}{l}\text { Kim et al } \\
2016 \text { (Kim et al. } \\
\text { 2016) }\end{array}$ & $\begin{array}{l}\text { Ranged from } 3.3 \text { to } 50.5 \text { mean } \\
\text { daily Chinese CDC Ministry of } \\
\text { Health and Welfare of Japan, and } \\
\text { the National Death Registry of } \\
\text { Taiwan }\end{array}$ & $\begin{array}{l}30 \text { different cities of } \\
\text { East Asia, 1979- } \\
2010\end{array}$ & $\begin{array}{l}\text { mean Temperature } \\
\text { diurnal Temperature } \\
\text { rang }\end{array}$ & $\mathrm{PM}_{10}, \mathrm{NO}_{2}$, and $\mathrm{SO} 2$ & $0-21$ & Time-Series & $\begin{array}{l}1^{\circ} \mathrm{C} \text { increase above mean } \\
\text { temperature for hot effect }\end{array}$ & ICD-10(I00-I99) \\
\hline
\end{tabular}




\begin{tabular}{|c|c|c|c|c|c|c|c|c|c|}
\hline NO & $\begin{array}{l}\text { Authors and } \\
\text { Years of } \\
\text { publication }\end{array}$ & Events No /Data source & $\begin{array}{l}\text { Location and } \\
\text { time period }\end{array}$ & $\begin{array}{l}\text { Main temperature } \\
\text { exposure } \\
\text { variable(s) }\end{array}$ & $\begin{array}{l}\text { Variables } \\
\text { Controlled }\end{array}$ & $\begin{array}{l}\text { Lags } \\
\text { (Days) }\end{array}$ & Study Design & $\begin{array}{l}\text { Effect estimate of } \\
\text { temperature/threshold }\end{array}$ & $\begin{array}{c}\text { Outcome } \\
\text { measurement }\end{array}$ \\
\hline 8 & $\begin{array}{l}\text { Yang et al } \\
\text { 2012(Yang et al. } \\
\text { 2012) }\end{array}$ & Guangzhou Bureau of Health & $\begin{array}{l}\text { Guangzhou, China } \\
\text { 2003-2007 }\end{array}$ & $\begin{array}{l}\text { Maximum, minimum } \\
\text { and Mean temperature }\end{array}$ & $\mathrm{PM}_{10}, \mathrm{NO}_{2}$, and $\mathrm{SO} 2$ & $0-25$ & Time-Series & $\begin{array}{l}\text { 99th to the 90th for hot } \\
\text { effect }\end{array}$ & $\begin{array}{l}\text { ICD-10(I00-I99) } \\
\text { Cardiovascular } \\
\text { mortality }\end{array}$ \\
\hline 9 & $\begin{array}{l}\text { Guo et al } \\
\text { 2012(Guo et al. } \\
\text { 2012b) }\end{array}$ & $\begin{array}{l}\text { 11,746, Bureau of Policy and } \\
\text { Strategy, Ministry of Public } \\
\text { Health, Thailand }\end{array}$ & $\begin{array}{l}\text { Thailand } \\
\text { 1999-2008 }\end{array}$ & $\begin{array}{l}\text { Maximum, Minimum } \\
\text { and Mean } \\
\text { Temperature }\end{array}$ & $\begin{array}{l}\text { PM10, O3, RH } \\
\text { Influenza }\end{array}$ & $0-21$ & Time-Series & $\begin{array}{l}\text { 99th compare } 75 \text { th for } \\
\text { hot effect vs } 1 \text { st compare } \\
\text { to } 25 \text { th for cold effect }\end{array}$ & $\begin{array}{l}\text { ICD-10(I00-I99) } \\
\text { Cardiovascular } \\
\text { mortality }\end{array}$ \\
\hline 10 & $\begin{array}{l}\text { Yi et al } \\
\text { 2015 (Yi \& Chan } \\
\text { 2015) }\end{array}$ & $\begin{array}{l}98,091 \\
\text { Hong Kong Census and } \\
\text { Statistics Department }\end{array}$ & $\begin{array}{l}\text { Hong Kong } \\
2002-2011\end{array}$ & $\begin{array}{l}\text { Maximum, Minimum } \\
\text { and Mean } \\
\text { Temperature }\end{array}$ & $\mathrm{PM}_{10}, \mathrm{NO}_{2}$, and $\mathrm{SO} 2$ & $0-21$ & Time-Series & $\begin{array}{l}\text { 99th compare } 75 \text { th for } \\
\text { hot effect vs } 1 \text { th compare } \\
\text { to } 25 \text { th for cold effect }\end{array}$ & $\begin{array}{l}\text { ICD-10(I00-I99) } \\
\text { Cardiovascular } \\
\text { mortality }\end{array}$ \\
\hline 11 & $\begin{array}{l}\text { Seposo et al } \\
2015 \text { (Seposo et } \\
\text { al. 2015) }\end{array}$ & $\begin{array}{l}14.7 \text { mortality per day Philippine } \\
\text { Statistics Authority-National } \\
\text { Statistics Office (PSA-NSO) }\end{array}$ & $\begin{array}{l}\text { Philippine } \\
\text { 2006-2010 }\end{array}$ & $\begin{array}{l}\text { daily average } \\
\text { temperature }\end{array}$ & seasonal effect & No & Time-Series & $\begin{array}{l}\text { 1th respective to MMT for } \\
\text { cold effect vs. 99th respective } \\
\text { to MMT for hot effect }\end{array}$ & $\begin{array}{l}\text { ICD codes (I00-I99) } \\
\text { Cardiovascular- } \\
\text { related mortality }\end{array}$ \\
\hline 12 & $\begin{array}{l}\text { Chen et al } \\
\text { 2014(Chen et al. } \\
\text { 2014) }\end{array}$ & $\begin{array}{l}126925 \\
\text { Death Register System } \\
\text { from Chinese CDC }\end{array}$ & $\begin{array}{l}\text { China } \\
\text { 2009-2011 }\end{array}$ & $\begin{array}{l}\text { Maximum, Minimum } \\
\text { and Mean } \\
\text { Temperature }\end{array}$ & $\mathrm{PM}_{10}, \mathrm{NO}_{2}$, and $\mathrm{SO} 2$ & $0-14$ & Time-Series & $\begin{array}{l}\text { 99th compare } 75 \text { th for } \\
\text { hot effect vs } 1 \text { st compare } \\
\text { to } 25 \text { th for cold effect }\end{array}$ & $\begin{array}{l}\text { ICD -10: (I00-I25) } \\
\text { Coronary artery } \\
\text { Disease }\end{array}$ \\
\hline 13 & $\begin{array}{l}\text { Guo et al } \\
\text { 2012 (Guo et al. } \\
\text { 2012a) }\end{array}$ & $\begin{array}{l}16559 \\
\text { Chinese CDC }\end{array}$ & $\begin{array}{l}\text { China } \\
\text { 2004-2008 }\end{array}$ & $\begin{array}{l}\text { Maximum, Minimum } \\
\text { and Mean } \\
\text { Temperature }\end{array}$ & $\mathrm{PM}_{10}$, and $\mathrm{NO} 2$ & $0-20$ & Time-Series & $\begin{array}{l}\text { 99th compare } 90 \text { th for } \\
\text { hot effect vs } 1 \text { st compare } \\
\text { to } 10 \text { th for cold effect }\end{array}$ & $\begin{array}{l}\text { ICD -10: (I00-I25) } \\
\text { Coronary artery } \\
\text { Disease }\end{array}$ \\
\hline 14 & $\begin{array}{l}\text { Kim et al 2015 } \\
\text { (Kim et al. 2015) }\end{array}$ & $\begin{array}{l}8.5 \text { mortality per day } \\
\text { Statistics Korea, } \\
\text { National Institute of } \\
\text { Environmental Research }\end{array}$ & $\begin{array}{l}\text { Korea } \\
1995-2011\end{array}$ & $\begin{array}{l}\text { Daily Mean } \\
\text { Temperature }\end{array}$ & $\begin{array}{l}\text { RH, holidays, Day of } \\
\text { Week, Time trends } \\
\mathrm{PM}_{10}, \mathrm{NO} 2\end{array}$ & $0-21$ & Time-Series & $\begin{array}{l}\text { 99th compare 90th for } \\
\text { hot effect vs } 10 \text { th } \\
\text { compare to } 25 \text { th for cold } \\
\text { effect }\end{array}$ & $\begin{array}{l}\text { ICD-10(I20-I59) } \\
\text { ICD-9(410-429) }\end{array}$ \\
\hline 15 & $\begin{array}{l}\text { Huang et al } \\
\text { 2015(Huang et al. } \\
\text { 2015) }\end{array}$ & $\begin{array}{l}552866 \\
\text { Chinese CDC }\end{array}$ & $\begin{array}{l}\text { China } \\
\text { 2006-2011 }\end{array}$ & Mean Temperature & $\begin{array}{l}\text { Seasonal trend, Day } \\
\text { of Week RH, } \\
\text { Duration of } \\
\text { sunshine, } \\
\text { Precipitation, } \\
\text { Atmospheric } \\
\text { Pressure }\end{array}$ & $0-21$ & Time-Series & $\begin{array}{l}1^{\circ} \mathrm{C} \text { increase from } 25^{\circ} \mathrm{C} \\
\text { for hot effect, } 1^{\circ} \mathrm{C} \\
\text { decrease from } 25^{\circ} \mathrm{C} \text { for } \\
\text { cold effect }\end{array}$ & ICD codes (I00-I99) \\
\hline 16 & $\begin{array}{l}\text { Yang et al } \\
\text { 2015(Yang et al. } \\
\text { 2015a) }\end{array}$ & $\begin{array}{l}57,806 \\
\text { central urban district } \\
\text { of Shanghai }\end{array}$ & $\begin{array}{l}\text { Shanghai, China } \\
\text { 1981-2012 }\end{array}$ & $\begin{array}{l}\text { Daily mean } \\
\text { Temperature }\end{array}$ & $\begin{array}{l}\text { Seasonality, Day of } \\
\text { Week } \\
\text { RH, Holidays, } \\
\text { population size }\end{array}$ & $0-28$ & Time-Series & $\begin{array}{l}99 \text { th compare } 90 \text { th for hot } \\
\text { effect vs } 1 \text { st compare to } 10 \text { th } \\
\text { for cold effect }\end{array}$ & $\begin{array}{l}\text { ICD-9 }:(390-459) \\
\text { ICD codes (I00-I99) }\end{array}$ \\
\hline
\end{tabular}




\begin{tabular}{|c|c|c|c|c|c|c|c|c|c|}
\hline NO & $\begin{array}{c}\text { Authors and } \\
\text { Years of } \\
\text { publication }\end{array}$ & Events No/Data source & $\begin{array}{l}\text { Location and } \\
\text { time period }\end{array}$ & $\begin{array}{c}\text { Main temperature } \\
\text { exposure } \\
\text { variable(s) } \\
\end{array}$ & $\begin{array}{l}\text { Variables } \\
\text { Controlled }\end{array}$ & $\begin{array}{l}\text { Lags } \\
\text { (Days) }\end{array}$ & Study Design & $\begin{array}{l}\text { Effect estimate of } \\
\text { temperature/threshold }\end{array}$ & $\begin{array}{c}\text { Outcome } \\
\text { measurement }\end{array}$ \\
\hline 17 & $\begin{array}{l}\text { Breitner et al } \\
2014 \text { (Breitner et } \\
\text { al. 2014) }\end{array}$ & $\begin{array}{l}\text { not mention } \\
\text { Bavarian State Office for } \\
\text { Statistics and Data Processing }\end{array}$ & $\begin{array}{l}\text { Bavaria, Germany } \\
\text { 1990-2007 }\end{array}$ & Mean Temperature & $\begin{array}{l}\text { Ozone, PM10 } \\
\text { Influenza epidemic, } \\
\text { time trend, Day of } \\
\text { week, RH, } \\
\text { barometric pressure }\end{array}$ & $0-14$ & Time-Series & $\begin{array}{l}\text { 99th compare } 90 \text { th for } \\
\text { hot effect vs } 1 \text { th } \\
\text { compared to } 10^{\text {th }} \text { for cold } \\
\text { effect }\end{array}$ & $\begin{array}{l}\text { ICD-9 }:(390-459) \\
\text { ICD codes (I00- } \\
\text { I99) }\end{array}$ \\
\hline 18 & $\begin{array}{l}\text { Wang et al } \\
\text { 2014(Wang et al. } \\
\text { 2014) }\end{array}$ & $\begin{array}{l}18,530 \\
\text { Suzhou Center for Disease } \\
\text { Control and Prevention }\end{array}$ & $\begin{array}{l}\text { Suzhou, China } \\
2005-2008\end{array}$ & Mean Temperature & $\mathrm{PM}_{10}, \mathrm{NO}_{2}$, and $\mathrm{SO} 2$ & $0-28$ & Time-Series & $\begin{array}{l}\text { 99th compare MMT }(26 \mathrm{C}) \\
\text { for hot effect vs } 1 \text { st compare } \\
\text { to MMT }(26 \mathrm{C}) \text { for cold effect }\end{array}$ & $\begin{array}{l}\text { ICD codes (I00- } \\
\text { I99) }\end{array}$ \\
\hline 19 & $\begin{array}{l}\text { Ma et al 2014(Ma } \\
\text { et al. 2014) }\end{array}$ & $\begin{array}{l}\text { not mention Municipal Center for } \\
\text { Disease Control and Prevention } \\
\text { (CDC) }\end{array}$ & $\begin{array}{l}\text { 17 large cities of } \\
\text { China } \\
\text { 1996-2008 }\end{array}$ & Mean Temperature & $\mathrm{PM}_{10}, \mathrm{NO}_{2}$, and $\mathrm{SO} 2$ & $0-28$ & Time-Series & $\begin{array}{l}\text { 99th compare } 75 \text { th for } \\
\text { hot effectvs } 1 \text { th compare } \\
\text { to } 25 \text { th for cold effect }\end{array}$ & $\begin{array}{l}\text { ICD codes (I00- } \\
\text { I99) }\end{array}$ \\
\hline 20 & $\begin{array}{l}\text { Yang et al } \\
2015 \text { (Yang et al. } \\
\text { 2015b) }\end{array}$ & $\begin{array}{l}23.8 \text { mortality per day } \\
\text { Guangzhou Bureau of Health }\end{array}$ & $\begin{array}{l}\text { Guangzhou, China } \\
\text { 2003-2007 }\end{array}$ & Mean Temperature & $\begin{array}{l}\text { PM10, NO2, and } \\
\text { SO2 Seasonality, } \\
\text { RH, Atmospheric } \\
\text { Pressure }\end{array}$ & $0-30$ & Time-Series & $\begin{array}{l}\text { 99th compare } 75 \text { th for } \\
\text { hot effect vs } 1 \text { st compare } \\
\text { to } 25 \text { th for cold effect }\end{array}$ & $\begin{array}{l}\text { ICD codes (I00- } \\
\text { I99) }\end{array}$ \\
\hline 21 & $\begin{array}{l}\text { Huang et al } \\
\text { 2014 (Huang et al. } \\
\text { 2014) }\end{array}$ & $\begin{array}{l}19,418 \\
\text { Chinese CDC }\end{array}$ & $\begin{array}{l}\text { Changsha, China } \\
\text { 2008-2011 }\end{array}$ & $\begin{array}{l}\text { daily Mean, } \\
\text { Maximum } \\
\text { and Minimum } \\
\text { temperature } \\
\end{array}$ & $\begin{array}{l}\text { long-term, } \\
\text { Seasonality } \\
\text { barometric pressure, } \\
\text { RH }\end{array}$ & $0-30$ & Time-Series & $\begin{array}{l}1^{\circ} \mathrm{C} \text { decrease from } 10^{\circ} \mathrm{C} \text { for } \\
\text { cold effect vs } 1{ }^{\circ} \mathrm{C} \text { increase } \\
\text { from } 29^{\circ} \mathrm{C} \text { fof hot effect }\end{array}$ & $\begin{array}{l}\text { ICD codes (I00- } \\
\text { I79) }\end{array}$ \\
\hline 22 & $\begin{array}{l}\text { Yu, et al(Yu et al. } \\
\text { 2011a) }\end{array}$ & $\begin{array}{l}22,805 \\
\text { Office of Economic and } \\
\text { Statistical Research of the } \\
\text { Statistical Research of the } \\
\text { Queensland Treasury } \\
\end{array}$ & $\begin{array}{l}\text { Brisbane, Australia } \\
\text { 1996-2004 }\end{array}$ & $\begin{array}{l}\text { Maximum, Minimum } \\
\text { Temperature }\end{array}$ & $\mathrm{PM} 10, \mathrm{NO} 2, \mathrm{O} 3$ & $0-31$ & Time-Series & $\begin{array}{l}1^{\circ} \mathrm{C} \text { increase from } 24^{\circ} \mathrm{C} \text { for } \\
\text { cold effect vs } 1{ }^{\circ} \mathrm{C} \text { decrease } \\
\text { from } 24^{\circ} \mathrm{C} \text { for cold effect }\end{array}$ & $\begin{array}{l}\text { ICD-9 }:(390-499) \\
\text { ICD codes (I00- } \\
\text { I99) }\end{array}$ \\
\hline 23 & $\begin{array}{l}\text { Chan, E, Y, Y } \\
\text { 2012 (Chan et al. } \\
\text { 2012) }\end{array}$ & $\begin{array}{l}129688 \\
\text { Hong Kong Census } \\
\text { And Statistics Department }\end{array}$ & $\begin{array}{l}\text { Hong Kong } \\
\text { 1998-2006 }\end{array}$ & $\begin{array}{l}\text { average daily mean } \\
\text { temperature }\end{array}$ & $\begin{array}{l}\mathrm{PM} 10, \mathrm{NO} 2, \mathrm{SO} 2, \\
\mathrm{O} 3 \\
\text { Day of the week and } \\
\text { holiday }\end{array}$ & $0-14$ & Time-Series & $\begin{array}{l}1{ }^{\circ} \mathrm{C} \text { increase from } 28.2^{\circ} \mathrm{C} \\
\text { for hot effect }\end{array}$ & $\begin{array}{l}\text { ICD9 390-459 } \\
\text { ICD 10 I00-199 }\end{array}$ \\
\hline 24 & $\begin{array}{l}\text { Wang, X } \\
2015 \text { (Wang et al. } \\
2015 \text { ) }\end{array}$ & $\begin{array}{l}\text { Not mentioned } \\
\text { Chinese CDC }\end{array}$ & $\begin{array}{l}\text { Chinese } \\
\text { 2007-2009 }\end{array}$ & Mean Temperature & $\begin{array}{l}\text { Seasonality, Time } \\
\text { trend, } \\
\text { PM10, NO2, SO2, } \\
\text { RH, Wind }\end{array}$ & $0-27$ & Time-Series & $\begin{array}{l}\text { 99th compare 90th for } \\
\text { hot effect vs } 1 \text { th compare } \\
\text { to } 10 \text { th for cold effect }\end{array}$ & ICD 10 I00-I99 \\
\hline 25 & $\begin{array}{l}\text { Bai, L } \\
2014 \text { (Bai et al. } \\
2014 \text { ) }\end{array}$ & $\begin{array}{l}5,610 \\
\text { Tibetan CDC }\end{array}$ & $\begin{array}{l}\text { china } \\
\text { 2008-2012 }\end{array}$ & Mean Temperature & 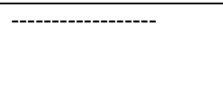 & $0-14$ & Time-Series & $\begin{array}{l}\text { 99th compare } 75 \text { th for } \\
\text { hot effect vs } 1 \text { th compare } \\
\text { to } 10 \text { th for cold effect }\end{array}$ & ICD 10 I00-I99 \\
\hline 26 & $\begin{array}{l}\text { Gomez-Acebo } \\
2013 \\
\text { (Gomez-Acebo et } \\
\text { al. 2013) }\end{array}$ & $\begin{array}{l}1252 \\
\text { Spanish National Institute for } \\
\text { Statistical }\end{array}$ & $\begin{array}{l}\text { Spain } \\
\text { 2004-2005 }\end{array}$ & $\begin{array}{l}\text { minimum } \\
\text { temperatures }\end{array}$ & $\begin{array}{l}\text { age, sex, underlying } \\
\text { disease }\end{array}$ & $0-6$ & Case-crossover & $\begin{array}{l}\text { 5th }(-13.8 \mathrm{C}) \text { compare } \\
\text { campare with over the } \\
5 \text { th }(1.8 \mathrm{C}) \text { for cold effect }\end{array}$ & ICD-10 I00-I99 \\
\hline
\end{tabular}


Bai L, Woodward A, and Liu Q. 2014. Temperature and mortality on the roof of the world: a time-series analysis in three Tibetan counties, China. Science of The Total Environment 485:41-48.

Breitner S, Wolf K, Devlin RB, Diaz-Sanchez D, Peters A, and Schneider A. 2014. Short-term effects of air temperature on mortality and effect modification by air pollution in three cities of Bavaria, Germany: a time-series analysis. Science of The Total Environment 485:49-61.

Chan EYY, Goggins WB, Kim JJ, and Griffiths SM. 2012. A study of intracity variation of temperaturerelated mortality and socioeconomic status among the Chinese population in Hong Kong. Journal of Epidemiology and Community Health 66:322-327.

Chen R, Li T, Cai J, Yan M, Zhao Z, and Kan H. 2014. Extreme temperatures and out-of-hospital coronary deaths in six large Chinese cities. Journal of Epidemiology and Community Health:jech-2014204012.

Goggins WB, Chan E, Yang C, and Chong M. 2013. Associations between mortality and meteorological and pollutant variables during the cool season in two Asian cities with sub-tropical climates: Hong Kong and Taipei. Environ Health 12:59.

Gomez-Acebo I, Llorca J, and Dierssen T. 2013. Cold-related mortality due to cardiovascular diseases, respiratory diseases and cancer: a case-crossover study. Public health 127:252-258.

Guo Y, Li S, Zhang Y, Armstrong B, Jaakkola JJ, Tong S, and Pan X. 2012a. Extremely cold and hot temperatures increase the risk of ischaemic heart disease mortality: epidemiological evidence from China. Heart:heartjnl-2012-302518.

Guo Y, Punnasiri K, Tong S, Aydin D, and Feychting M. 2012b. Effects of temperature on mortality in Chiang Mai city, Thailand: a time series study. Environ Health 11:10.1186.

Huang J, Wang J, and Yu W. 2014. The lag effects and vulnerabilities of temperature effects on cardiovascular disease mortality in a subtropical climate zone in China. International journal of environmental research and public health 11:3982-3994.

Huang Z, Lin H, Liu Y, Zhou M, Liu T, Xiao J, Zeng W, Li X, Zhang Y, and Ebi KL. 2015. Individual-level and community-level effect modifiers of the temperature-mortality relationship in 66 Chinese communities. BMJ open 5:e009172.

$\mathrm{Kim} \mathrm{H}$, Heo J, Kim H, and Lee J-T. 2015. Has the impact of temperature on mortality really decreased over time? Science of The Total Environment 512:74-81.

Kim J, Shin J, Lim Y-H, Honda Y, Hashizume M, Guo YL, Kan H, Yi S, and Kim H. 2016. Comprehensive approach to understand the association between diurnal temperature range and mortality in East Asia. Science of The Total Environment 539:313-321.

Lin Y-K, Chang C-K, Wang Y-C, and Ho T-J. 2013. Acute and Prolonged Adverse Effects of Temperature on Mortality from Cardiovascular Diseases. PLoS one 8:e82678.

Ma W, Chen R, and Kan H. 2014. Temperature-related mortality in 17 large Chinese cities: How heat and cold affect mortality in China. Environmental Research 134:127-133.

Qiao Z, Guo Y, Yu W, and Tong S. 2015. Assessment of short-and long-term mortality displacement in heat-related deaths in Brisbane, Australia, 1996-2004. Environmental Health Perspectives 123:766.

Seposo XT, Dang TN, and Honda Y. 2015. Evaluating the effects of temperature on mortality in manila city (Philippines) from 2006-2010 using a distributed lag nonlinear model. International journal of environmental research and public health 12:6842-6857. 
Tian Z, Li S, Zhang J, Jaakkola JJ, and Guo Y. 2012. Ambient temperature and coronary heart disease mortality in Beijing, China: a time series study. Environ Health 11:10.1186.

Wang C, Chen R, Kuang X, Duan X, and Kan H. 2014. Temperature and daily mortality in Suzhou, China: a time series analysis. Science of The Total Environment 466:985-990.

Wang X, Li G, Liu L, WesterdahI D, Jin X, and Pan X. 2015. Effects of Extreme Temperatures on CauseSpecific Cardiovascular Mortality in China. International journal of environmental research and public health 12:16136-16156.

Yang C, Meng X, Chen R, Cai J, Zhao Z, Wan Y, and Kan H. 2015a. Long-term variations in the association between ambient temperature and daily cardiovascular mortality in Shanghai, China. Science of The Total Environment 538:524-530.

Yang J, Ou C-Q, Ding Y, Zhou Y-X, and Chen P-Y. 2012. Daily temperature and mortality: a study of distributed lag non-linear effect and effect modification in Guangzhou. Environ Health 11:63.

Yang J, Ou C-Q, Guo Y, Li L, Guo C, Chen P-Y, Lin H-L, and Liu Q-Y. 2015b. The burden of ambient temperature on years of life lost in Guangzhou, China. Scientific reports 5.

Yang J, Yin P, Zhou M, Ou C-Q, Guo Y, Gasparrini A, Liu Y, Yue Y, Gu S, and Sang S. 2015c. Cardiovascular mortality risk attributable to ambient temperature in China. Heart:heartjnl-2015-308062.

Yi W, and Chan AP. 2015. Effects of temperature on mortality in Hong Kong: a time series analysis. International journal of biometeorology 59:927-936.

Yu W, Hu W, Mengersen K, Guo Y, Pan X, Connell D, and Tong S. 2011a. Time course of temperature effects on cardiovascular mortality in Brisbane, Australia. Heart 97:1089-1093.

Yu W, Mengersen K, Hu W, Guo Y, Pan X, and Tong S. 2011b. Assessing the relationship between global warming and mortality: lag effects of temperature fluctuations by age and mortality categories. Environmental Pollution 159:1789-1793. 


\section{Table 2 (on next page)}

Heat and cold exposure effect in lag days and low and high educational levels 
1

2 Table 2. The cumulative relative risks ( $95 \%$ confidence interval) of cold and heat exposure on

3 cardiovascular mortality based on lag days and educational levels.

4

\begin{tabular}{llll}
\hline \multirow{2}{*}{ Variabels } & & \multicolumn{1}{c}{ Cold effect } & Heat effect \\
\hline \multirow{3}{*}{ Lag Days } & Lag 0 & $1.01(1.00$ to 1.02$)$ & $1.04(1.03$ to 1.05$)$ \\
\cline { 2 - 4 } & Lag 0-3 & $1.06(1.05$ to 1.08$)$ & $1.10(1.08$ to 1.12$)$ \\
\cline { 2 - 4 } & Lag 0-7 & $1.05(1.03$ to 1.07$)$ & $1.14(1.09$ to 1.17$)$ \\
\cline { 2 - 4 } & Lag 0-13 & $1.09(1.07$ to 1.10$)$ & $1.11(1.08$ to 1.15$)$ \\
\cline { 2 - 4 } & Lag 0-21 & $1.06(1.05$ to 1.07$)$ & $1.12(1.06$ to 1.17$)$ \\
\cline { 2 - 4 } & Lag 0-28 & $1.07(1.05$ to 1.08$)$ & $1.13(1.07$ to 1.17$)$ \\
\hline \hline \multirow{2}{*}{ Educational levels } & Low Educational Level & $1.035(1.031$ to 1.04$)$ & $1.03(1.02$ to 1.04$)$ \\
\cline { 2 - 4 } & High Educational Level & $1.014(1.011$ to 1.02$)$ & $1.011(1.00$ to 1.015$)$. \\
\hline
\end{tabular}

5 


\section{Table 3(on next page)}

The dose-response relationship between the risk of cardiovascular mortality (\%) and latitude, longitude, lag day and mean annual temperature 
Tables 3.The dose-response relationship between the temperature associated increase in risk of cardiovascular mortality (\%) and latitude,longitude,lag day and mean anuual temperature.

\begin{tabular}{lllll}
\hline \multirow{2}{*}{ Explraitory Variable } & \multicolumn{1}{c}{ Cold Exposure } & Heat Exposure & P value \\
\cline { 2 - 5 } & $\begin{array}{l}\text { Coefficient } \\
(95 \% \text { Conf. Interval) }\end{array}$ & P value & $\begin{array}{l}\text { Coefficient } \\
(95 \% \text { Conf. Interval) }\end{array}$ & 0.026 \\
\hline $\begin{array}{l}\text { One-degree change in } \\
\text { latitude }\end{array}$ & $0.020(0.0060-0.0356)$ & 0.009 & $0.007(0.0008-0.0124)$ & 0.655 \\
\hline $\begin{array}{l}\text { One-degree change in } \\
\text { longitude }\end{array}$ & $0.007(0.0003-0.0146)$ & 0.042 & $0.0006(-0.002-0.004)$ & 0.385 \\
\hline $\begin{array}{l}\text { One-day increase in lag } \\
\begin{array}{l}\text { One-degree increase in } \\
\text { mean anuual temperature }\end{array}\end{array}$ & $-0.0167(-0.055-0.021)$ & 0.366 & $0.006(-0.009-0.022)$ & 0.474 \\
\hline Constant variable & $248.867(17.507-0.019-0.072)$ & 0.240 & $0.008(-0.0151-0.031)$ & 0.004 \\
\hline
\end{tabular}

* Significant at $95 \% \mathrm{Cl}$ 